\title{
Late Quaternary tectonic activity and lake level change in the Rukwa Rift Basin
}

\author{
D. DELVAUX,' F. KERVYN, ${ }^{1}$ E. VITTORI, ${ }^{2}$ R. S. A. KAJARA ${ }^{3}$ \\ and E. KILEMBE 4 \\ ${ }^{1}$ Royal Museum for Central Africa, B-3080 Tervuren, Belgium \\ ${ }^{2}$ ANPA, Via Vitaliano Brancati, 48, 00144 Roma, Italy \\ ${ }^{3}$ MADINI, Box 903 Dodoma, Tanzania \\ ${ }^{4}$ TPDC, Exploration-Production, Box 2774 Dar-es-Salaam, Tanzania
}

\begin{abstract}
Interpretation of remotely sensed images and air photographs, compilation of geological and topographical maps, morphostructural and fault kinematic observations and ${ }^{14} \mathrm{C}$ dating reveal that, besides obvious climatic influences, the lake water extent and sedimentation in the closed hydrological system of Lake Rukwa is strongly influenced by tectonic processes. A series of sandy ridges, palaeolacustrine terraces and palaeounderwater delta fans are related to an Early Holocene high lake level and subsequent progressive lowering. The maximum lake level was controlled by the altitude of the watershed between the Rukwa and Tanganyika hydrological systems. Taking as reference the present elevation of the palaeolacustrine terraces around Lake Rukwa, two orders of vertical tectonic movement are evidenced:

i) a general uplift centred on the Rungwe Volcanic Province between the Rukwa and Malawi Rift Basins; and

ii) a tectonic northeastward tilting of the entire Rukwa Rift Basin, including the depression and rift shoulders.

This is supported by the observed hydromorphological evolution. Local uplift is also induced by the development of an active fault zone in the central part of the depression, in a prolongation of the Mbeya Range-Galula Fault system. The Ufipa and Lupa Border Faults, bounding the Rukwa depression on the southwestern and northeastern sides, respectively, exert passive sedimentation control only. They appear inactive or at least less active in the Late Quaternary than during the previous rifting stage. The main Late Quaternary tectonic activity is represented by dextral strike-slip movement along the Mbeya Range-Galula Fault system, in the middle of the Rukwa Rift Basin, and by normal dip-slip movements along the Kanda Fault, in the western rift shoulder. 1998 Elsevier Science Limited.
\end{abstract}

Résumé-L'interprétation d'imageries satellitaires et de photographies aériennes, la compilation de cartes géologiques et topographiques, des observations morphologiques et cinématiques des failles et des datations au ${ }^{14} \mathrm{C}$ montrent que, en dehors des influences climatiques évidentes, l'étendue lacustre et la sédimentation dans le système hydrologique fermé du lac Rukwa sont influencés par la tectonique. Une série de rides sablonneuses (sandy ridges), de terrasses et de deltas souslacutres fossiles sont mis en relation avec un ancien haut niveau du lac Rukwa au Holocène précoce, et son abaissement progressif. Le niveau lacustre maximum était contrôlé par l'altitude du seuil de partage des eaux entre les bassins de Rukwa et Tanganyika. En prenant comme référence l'élévation des terrasses paléolacustres en bordure du bassin de Rukwa, deux types de mouvements verticaux sont mis en évidence:

i) un soulèvement en forme de dôme, centré sur la Province volcanique du Rungwe, entre les bassins de Rukwa et de Malawi; et ii) un basculement vers le nord-ouest de I'ensemble du bassin de Rukwa, y compris 
avec les épaules de rift, mais sans mouvement differentiels entre les épaules et la dépression.

Ceci est déduit de l'observation de l'évolution hydro-morphologique. Un soulèvement local est également associé à une zone de faille active dans le centre de la dépression, en prolongement du système faillé du Mbeya Range-Galula. Les failles bordières de Ufipa et Lupa, qui limitent la dépression de Rukwa, respectivement au sud-ouest et au nord-est, n'exercent qu'un contrôle passif de la sédimentation. Elles apparaissent inactives ou moins actives durant le Quaternaire tardif que dans le stade de riftogenèse précédent. L'activité récente principale est représentée par des mouvements décrochants dextres le long du système faillé de Mbeya Range-Galula, au centre du bassin de Rukwa, et par des mouvements normaux le long de la faille de Kanda, dans l'épaule ouest du bassin de Rukwa. 1998 Elsevier Science Limited.

(Received 3 March 1997: revised version received 4 October 1997)

\section{INTRODUCTION}

The tectonic depression of Lake Rukwa belongs to the western branch of the East African Rift System (McConnell, 1972). The Rukwa Rift Basin is located in the relay zone between the Tanganyika and Malawi (Nyasa) rift valleys (Fig. 1). With the latter it forms the TanganyikaRukwa-Malawi (TRM) lineament trending northeast. Kazmin (1980) first proposed that the TRM lineament formed an intracontinental transform fault zone, along which the Rukwa Rift Basin is believed to have opened as a pullapart basin in an oblique, northwest-southeast extension. This model was adopted by Chorowicz and Mukonki (1980) and supported by many others on the basis of the analyses of satellite images, the observation of fault slip indicators in the Precambrian basement along the major border faults and the interpretation of industrial seismic profiles (e.g. Tiercelin et al., 1988; Kilembe and Rosendahl, 1992; Wheeler and Karson, 1994). In contrast, Morley et al. (1992) favoured an opening of the Rukwa Rift Basin in a northeast-soutwest direction, suborthogonal to its general trend.

The major problem with the proposed mechanisms is the lack of precise timing. Mbede (1993) insists on the multistage evolution of the Rukwa Rift Basin, with various extension directions during its evolution since the Late Palaeozoic. In the Rungwe Volcanic Province and in north Malawi, Delvaux et al. (1992) and Ring et al. (1992), recognised several changes in kinematic regime during the Late Cenozoic. Palaeostress investigations in dated sediments and volcanics and the use of the inverse method for stress reconstructions (as in Angelier, 1989) showed that the Late Tertiary period (Late
Miocene-Pliocene) is characterised by a semiradial extensional stress field, with the opening of both the northwest trending basins (Rukwa Basin, Songwe Valley, Livingstone Basin) and the northeast trending Usangu depression (Delvaux et al., 1992). In the Middle Pleistocene, a stress inversion led to a new, strike-slip stress regime with a north-south horizontal principal compression. The kinematics of faulting changed completely. Normal faulting along the major fault zones ceased, or was strongly reduced, and only some of them were reactivated by strike-slip faulting (dextral movement along northwest trending faults and sinistral movement along northeast trending faults). This kinematic change was correlated with a similar change that occurred in the Kenya Rift at the same period (Strecker et al., 1990; Delvaux, 1993a).

In this study, the Late Quaternary active tectonics and lake level change of the Rukwa Rift Basin are investigated to help answer the following questions:

i) what is the expression of Late Quaternary tectonic activity and how does it differ from the older tectonic activity?

ii) where is the main fault activity at the surface?

iii) were the major rift border faults still active in the Late Quaternary?

iv) what is the Late Quaternary kinematics of faulting?

v) what kind of vertical movement affects the area? and

vi) what are the respective roles of active tectonics and climate in controlling the recent sedimentation and hydrology of Lake Rukwa?

Presently Lake Rukwa is a closed hydrological system, however during an earlier more humid 


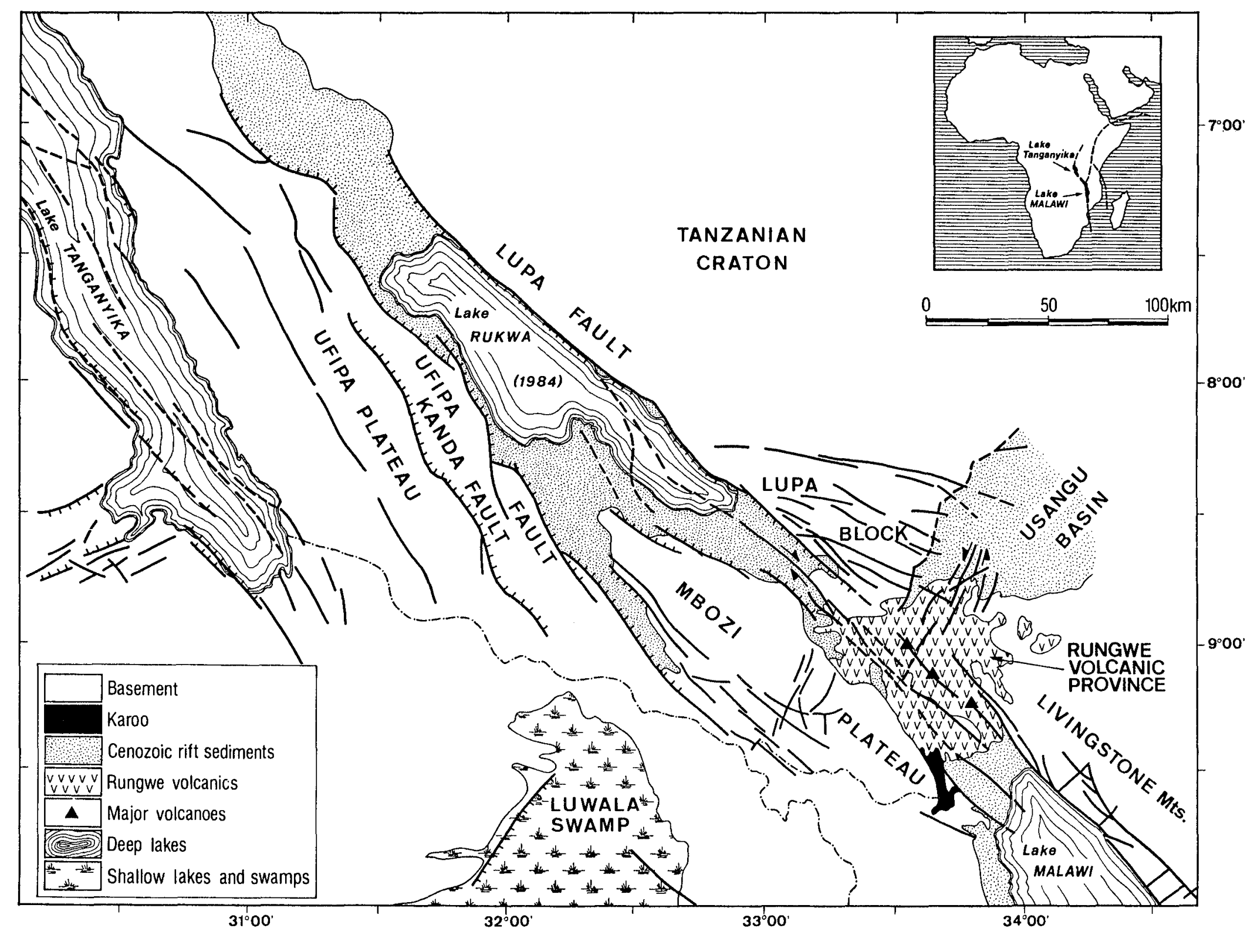


climatic phase it overflowed into Lake Tanganyika. A series of palaeolacustrine terraces and sandy ridges are well preserved along the flanks of the rift and in the valley floor. The altitude of the upper terrace and sandy ridge can be correlated with the altitude of the watershed. The age of the last high stand of the lake is estimated at the Early Holocene, also corroborated by preliminary ${ }^{14} \mathrm{C}$ dating. The altitudes of the lacustrine terraces with reference to the present lake level reveal differential vertical movements since the last high lake stand. This is also supported by the long-term trends in hydromorphological evolution and the deformation of palaeoerosional surfaces. Observation of tectonic deformation in the lacustrine terraces and in the recent sediments of the lake floor have allowed the identification of active faults. Morphostructural and microstructural investigations were made to determine the Late Quaternary fault kinematics.

\section{GEOLOGICAL SETTING}

The northwest trending Rukwa Rift Basin is 360 $\mathrm{km}$ long and $40-60 \mathrm{~km}$ wide. It is occupied in its eastern part by a wide but shallow lake, whose water level presently lies at an average elevation of $802 \mathrm{~m}$. The lake level and the surface area occupied by the water change rapidly due to climatic fluctuations. The lake, which now covers about half of the depression, was almost dry during the preceding century, but used to occupy almost the whole basin in the Early Holocene (Kennerley, 1962).

The Rukwa Rift developed within the northwest-southeast trending Palaeoproterozoic Ubende Belt, from which it reactivates mainly Neoproterozoic sinistral shear zones of the same trend (Theunissen et al., 1992; Lenoir et al., 1994; Theunissen et al., 1996). The northwest trending Rukwa depression is bordered on its northeastern side by the Lupa Fault and the Tanzanian Craton, and on its southwestern side by the Ufipa Fault and the Ufipa uplifted block. The stratigraphy and structure of the Rukwa depression is relatively well known (Wescott et al., 1991; Morley et al., 1992; Kilembe and Rosendahl, 1992). The depth of the Precambrian basement ranges from $4000 \mathrm{~m}$ in the northern half, to $11,000 \mathrm{~m}$ in the southern half (Peirce and Lipkov, 1988; Morley et al., 1992). The overall structure is mostly that of a symmetric graben in the northern part of the depression, grading into two opposing half-grabens in the southern part, with diverging dips of sedimentary layers towards the border faults. At the southeastern extremity of the depression, the two half-grabens are progressively isolated from each other by the Mbozi block. The eastern branch (Songwe Valley) is connected to the northern extremity of the Malawi Rift (Livingstone or Karonga Basin) and to the transverse Usangu depression, in the Rungwe Volcanic Province. The western branch (Msangano Trough) dies out progressively to the southwest.

The earliest sedimentary record within the Rukwa Graben consists of deposits of the Late Carboniferous to Early Jurassic Karoo Supergroup. The next sedimentary unit is the fluviatile Red Sandstone Group of controversial Late Jurassic/Early Cretaceous or Miocene age (Dypvik et al., 1990; Wescott et al., 1991; Kilembe and Rosendahl, 1992; Mbede, 1993; Damblon et al., 1998). A shallow lacustrine to fluviatile environment was then established, with the deposition of Pliocene-Early Pleistocene Older Lake Beds and Late Pleistocene-Holocene Younger Lake Beds (Quennell et al., 1956).

Volcanism in the Rungwe Province started in the Late Miocene, about $8 \mathrm{Ma}$ ago, and is still active in the Holocene (Ebinger et al., 1993). Williams et al. (1993) reveal the presence of discrete ash horizons in Holocene sediments from northern Lake Malawi, providing evidence for at least six eruptive episodes in the Rungwe volcanic field between 9000 and $150 \mathrm{yr}$. BP. The youngest tuff deposits in the Rungwe area have ${ }^{14} \mathrm{C}$ ages of around $11,000 \mathrm{yr}$. BP (Crossley, 1982; Ebinger et al., 1989) and the youngest eruption occurred in the Kiejo volcano, 200 years ago (Harkin, 1960).

Recent tectonic activity in the Rungwe region, which acts as a structural link between the north Malawi and Rukwa Rift Basins, was demonstrated by Delvaux and Hanon (1993). Recent and active faults, fossil travertine, active hydrothermal springs and gas vents, Late Quaternary volcanic eruptions and seismicity attest to this neotectonic activity. A local

\footnotetext{
Figure 2. Hydromorphological map of the Rukwa Rift Basin showing the succession of sandy ridges and swamps of decreasing altitude from the northern extremity of the Rukwa Depression to the present-day northern shore, and the surface occupied by water in 1950, 1977 and 1984. Circled numbers indicate sites cited in the text. 1: Luika River falls; 2: Saza River falls; 3: Mkwajuni; 4: fault scarp between Luika and Saza Falls; 5: Kilamba River falls near Muse; 6: Kavuu River section near Rungwa Ridge; 7: Kanda Fault scarp near Sumbawanga; 8: Kanda Fault scarp near Kaengesa; 9: Njelenje (Mbya Range Fault); 10. canyon of the Songwe River; 11: canyon of the lpwizi River. S: Sumbawanga; T: Tunduma; M: Mbeva.
} 


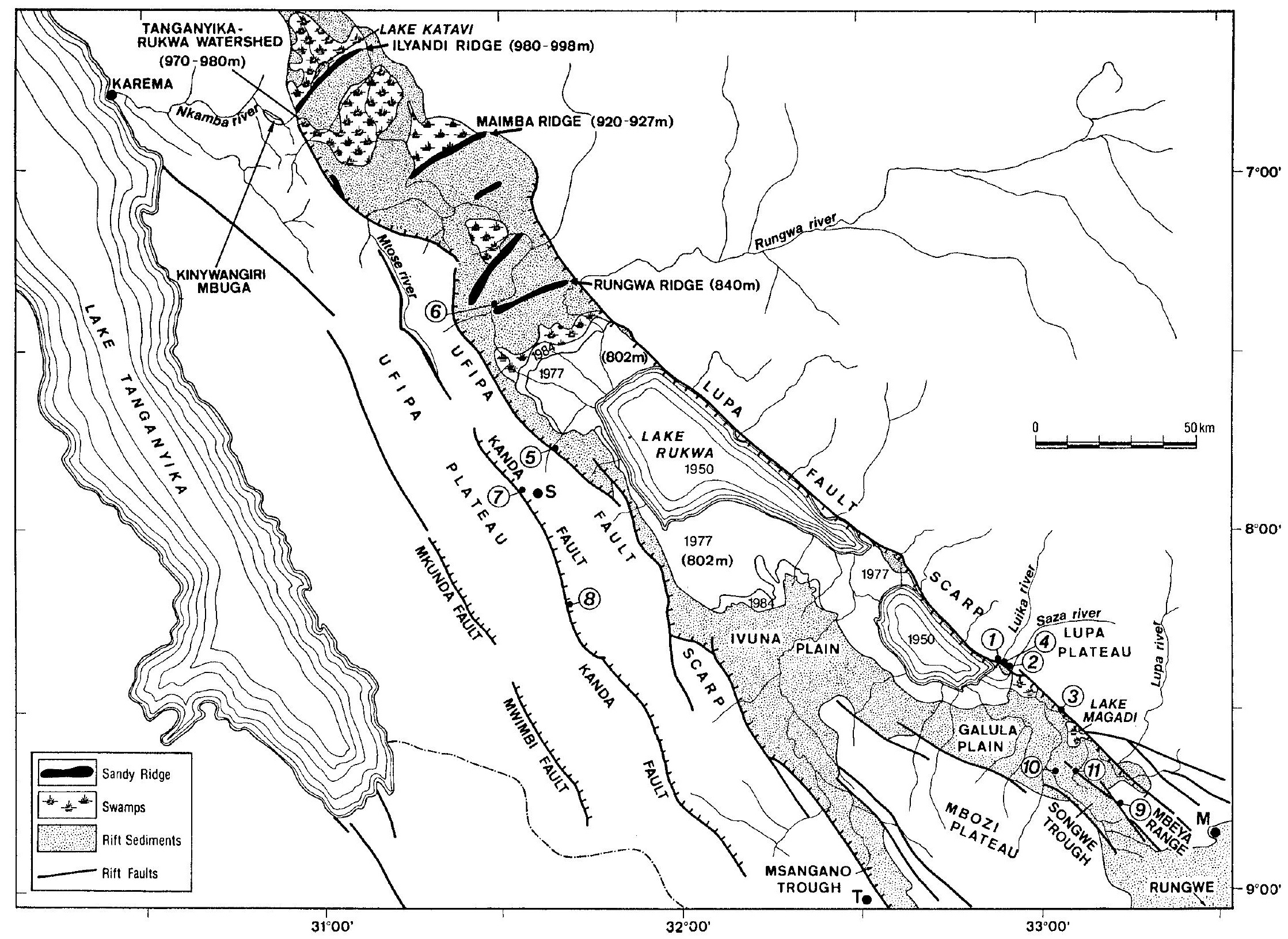


network of seismic stations operating since 1992 in the Mbeya area provides evidence for high seismic activity (Camelbeeck, 1992; Camelbeeck and Iranga, 1996). Moderate to large earthquakes periodically hit the region (e.g. Ambraseys and Adams, 1991).

The Neotectonic period is considered here to correspond to the last first-order geodynamic regime that affects the region under consideration. For the Rukwa-Malawi region, the last change in tectonic regime is believed to have occurred between 1 and $0.5 \mathrm{Ma}$ (Delvaux et al., 1992; Ring et al., 1992), and therefore the Neotectonic period covers the Middle Pleistocene-Holocene.

\section{PALAEOLACUSTRINE TERRACES AND LAKE LEVEL FLUCTUATIONS}

This section investigates the palaeolacustrine terraces and Late Quaternary lake level fluctuations in the Rukwa depression, considering successively the sandy ridges in the basin floor, the watershed and palaeolacustrine terraces along the basin flanks, and terminating with an age estimation of the last high stand of the lake. The elevations used here were either taken from the 1:50 000 topographical map of Tanzania or measured at $\pm 10 \mathrm{~m}$ accuracy with an altimeter calibrated to the lake level.

\section{Sandy ridges and palaeo-outlet of Lake Rukwa} In the basin floor, north of Lake Rukwa, well defined, slightly curved low ridges are evidenced in air photos and Landsat MSS images. Some are mentioned on geological and topographical maps as "Sandy Ridges". They are almost perpendicular to the rift trend and were interpreted by Tiercelin et al. (1988) as curved normal faults. Following this interpretation and assuming that the Lupa and Ufipa Faults have a dextral strike-slip movement, Tiercelin et al. (1988) further suggested that the Rukwa Rift depression developed as a typical pull-apart basin. A different interpretation of these ridges will be given here.

Detailed examination of Landsat images and topographical maps reveals a succession of curved ridges of decreasing elevation from the northern extremity of the Rukwa depression to the present-day lake (Fig. 2). The floor of the depression on which they lie slowly but regularly descends towards the southeast. The most prominent of these ridges are the llyandi Ridge (980-998 $\mathrm{m}$ a.s.1.), the Major Maimba Ridge (920-927 $\mathrm{m}$ a.s.l.) and the Rungwa Ridge 1840 $m$ a.s.I.). In addition, less pronounced ridges are found at $900 \mathrm{~m}$ (Lower Maimba Ridge), 880 and $860 \mathrm{~m}$ a.s.l. For reference, the lake shore was at $\pm 802 \mathrm{~m}$ a.s.l. in the years 1977-1978. These ridges are separated by 10 to $45 \mathrm{~km}$, with a total distance from the llyandi Ridge to the northwestern shore of Lake Rukwa of 115 $\mathrm{km}$. The ridges modify the drainage pattern and small lakes or swamps often develop behind them. Examples are the Katavi Lake and swamp north of the Ilyandi Ridge, the Chada Lake and Nsakasa Mbuga behind the Major Maimba Ridge and the Isimba swamp behind the unnamed ridge at $860 \mathrm{~m}$ a.s.l. (Fig. 2). Direct field observation of the llyandi and Rungwa Ridges has shown that they are relatively symmetrical, up to $40 \mathrm{~m}$ high and composed mostly of sand.

Based on these characteristics, the "Sandy Ridges" are unlikely to be tectonic scarps associated with curved normal faults. They are interpreted here as abandoned shore lines caused by the stepwise retreat of the lake. They resemble offshore sand bars that form by the combined action of waves and wind when the water depth is shallowing to a critical value, causing the waves to break. Typical swampy pools have formed behind the sand bars and are isolated from the open lake. Such modern equivalents are known from both the northern end of Lake Malawi (Nyasa) in Matema and Lake Tanganyika (southern side of the Mahali uplift). They are all orientated at a high angle to the long axis of the lakes and subjected to strong winds.

The watershed between the Rukwa and the Tanganyika drainage basins lies at an elevation of 970-980 m a.s.l. at the western extremity of the llyandi sandy ridge. It separates the swampy area belonging to the Rukwa depression at 953 $\mathrm{m}$ a.s.l. from the swamps of the Kinywangiri Mbuga (762 $\mathrm{m}$ a.s.l.), which feeds the Nkamba River. The latter flows westwards to Lake Tanganyika (762 m a.s.I.) via Karema (Fig. 2). The llyandi sandy ridge develops mostly above $980 \mathrm{~m}$ a.s.l., culminating at $998 \mathrm{~m}$ a.s.l., therefore, there can be little doubt that the llyandi Ridge corresponds to the uppermost level of Lake Rukwa and formed when it was overflowing into Lake Tanganyika through the watershed. The top of the llyandi Ridge is a few metres higher than the probable corresponding lake level, as is normally the case for such sand bars.

\section{Palaeolacustrine terraces along the Lupa and Ufipa Border Faults}

Along the escarpments of both the Lupa and Ufipa Border Faults, palaeolacustrine terraces are 


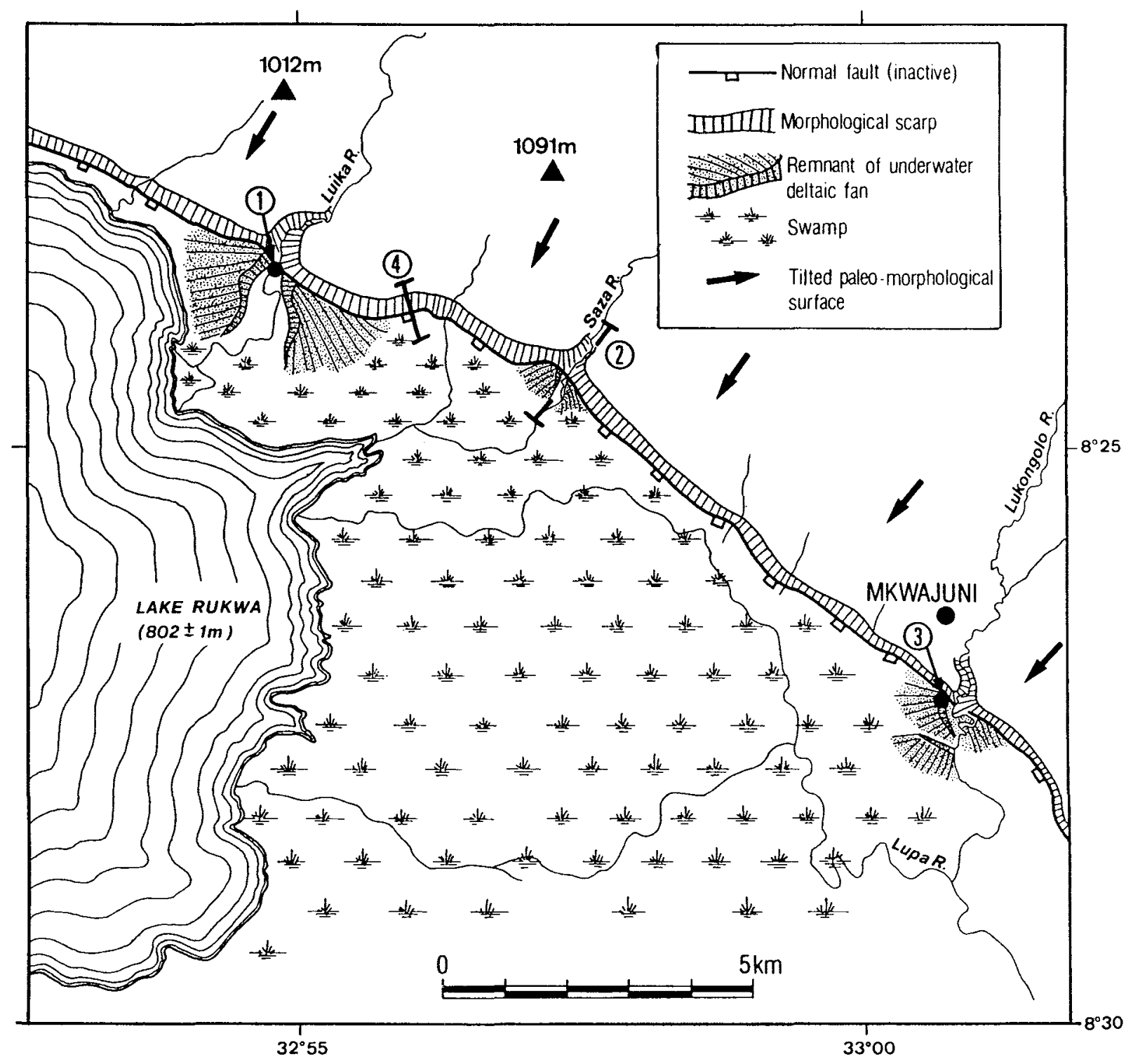

Figure 3. Lupa Fault scarp near Mkwajuni: morphostructural map interpreted from air photographs and field observations (indices 1-4 in Fig. 2). Location of sections for Figs 4 and 5.

observed locally, in connection with the main drainage lines from the Lupa and Ufipa Plateaus. The main rivers developed waterfalls of a few tens of metres, when crossing the fault escarpments (e.g. the Saza and Luika Rivers along the Lupa Border Fault and the Kilambwa and Mbede Rivers along the Ufipa Border Fault).

Along the Lupa Border Fault, Quaternary deposits are found at the mouth of important rivers emerging from the escarpment (Fig. 3). They lie against the fault and have the characteristic shape of a horse shoe with a waterfall in the centre. They are made of lacustrine and fluvial deposits. The surface of these deposits, departing from the escarpment, display a step-like profile gently sloping towards the lake. They are interpreted as sediments deposited under a higher lake level, forming underwater delta fans at the mouth of the rivers flowing through the fault scarp. The observed deposits lie undisturbed against the fault escarpment, apparently sealing the Lupa Border Fault. Air photo interpretation and direct field observations reveal no traces of neotectonic activity in these deposits.

The palaeodelta fans have a typical stepped profile in different places along the Lupa Border Fault, probably corresponding to a series of lacustrine terraces of decreasing altitude, developed during the stepwise progressive lowering of the lake level. At the mouth of the Luika River (index 1 in Figs 2 and 3), the top of 


\section{NE}

\section{LUPA FAULT ESCARPMENT (Saza falls)}

$850-855 \mathrm{~m}$ a.s.l.

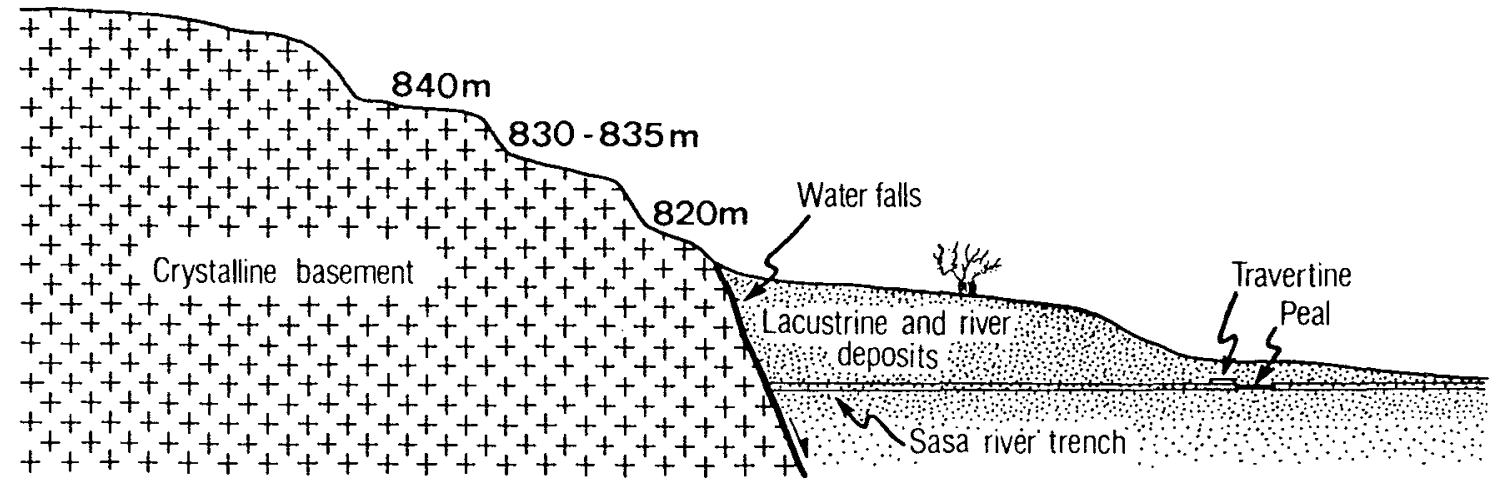

Figure 4. Schematic cross-section of Quaternary deposits at the Sasa falls location (index 2 in Figs 2 and 3.)

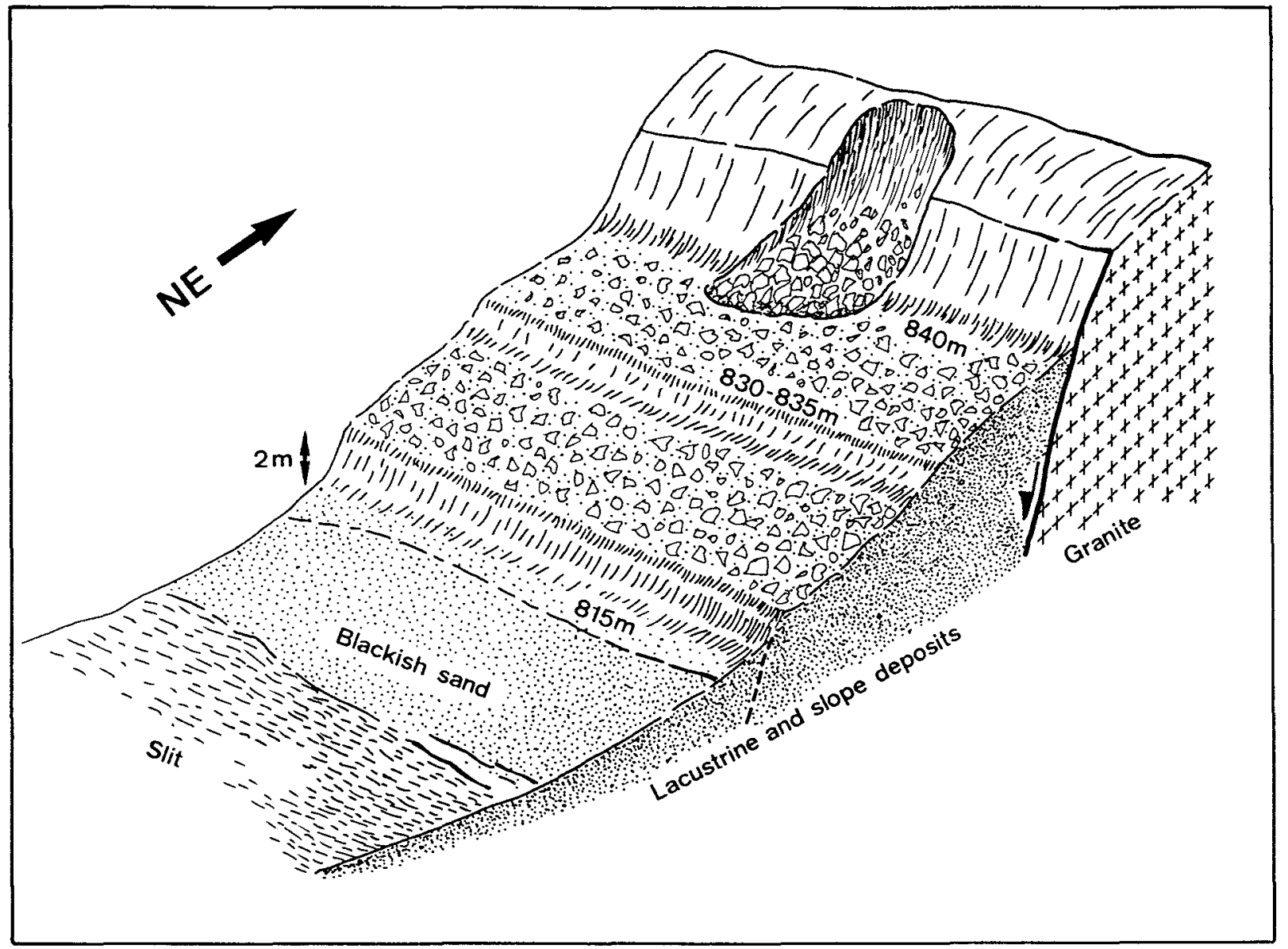

Figure 5. Schematic profile at the base of the Lupa Escarpment between Luika and Saza falls (index 4 in Figs 2 and 3 ).

the water fall is at $840 \mathrm{~m}$ a.s.l. At the Saza Falls (index 2 in Figs 2 and 3; Fig. 4), the top of fault scarp is at $850-855 \mathrm{~m}$ a.s.l., the upper surface of Quaternary deposit against the fault scarp is at $840 \mathrm{~m}$ a.s.l., an intermediate terrace is at 830-835 $\mathrm{m}$ a.s.l. and the lower terrace is at $820 \mathrm{~m}$ a.s.l. At Mkwajuni Village (index 3 in Fig. 3), a similar alluvial fan of sand and pebbles 


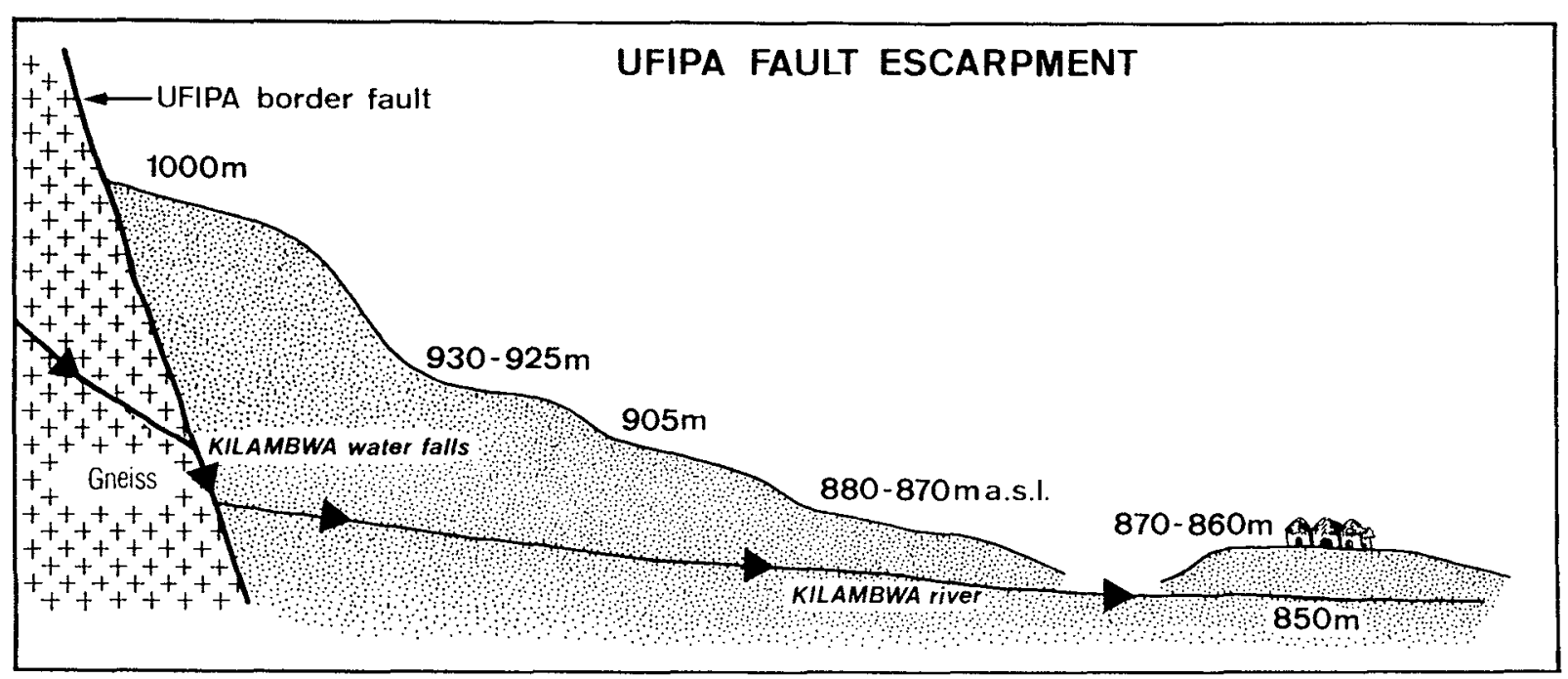

Figure 6. Schematic cross-section of the Quaternary deposits at the base of the Ufipa Fault scarp, north of Muze (index 5 in Fig. 2). Terraced profile of the underwater palaeodelta.

is observed along the Lukolongo River, with the summit of the fault scarp at $900 \mathrm{~m}$, and gently sloping surfaces at $840-860 \mathrm{~m}$ (upper terrace) and $810-815 \mathrm{~m}$ a.s.l. The base of the fault scarp between the Luika and Saza Deltas (index 4 in Fig. 3; Fig. 5) also have a stepped profile, with gently sloping surfaces to $840,830-835$ and $815 \mathrm{~m}$ a.s.l. All these altitudes are remarkably coherent. This suggests a past succession of high lake levels at $840-860 \mathrm{~m}, 830-835 \mathrm{~m}$ and $810-820 \mathrm{~m}$ a.s.l. along the central portion of the Lupa Border Fault.

Along the Ufipa Border Fault, at the mouth of the Kilambwa River falls near Muze Village (index 5 in Fig. 2), a palaeounderwater delta fan also abuts the base of the fault scarp (Fig. 6). No evidence of recent faults cutting the Quaternary deposits was found. Any tectonic mobility along this escarpment should therefore be on smaller and much younger faults in front of the main escarpment and terraces. There is thus a similarity with the opposite side of the Rukwa depression, along the Lupa Fault, however the terraces and waterfalls are at a higher elevation with respect to the ones on the Lupa side. Near Muze, the terraced surfaces gently sloping toward the valley axis are at $1000 \mathrm{~m}$ (uppermost one, at contact with the fault scarp), 925-930 $\mathrm{m}, 905 \mathrm{~m}, 880-870 \mathrm{~m}$ and $850 \mathrm{~m}$ (village) a.s.l. This relative difference in elevation will be discussed later.

\section{Water level fluctuations in the Holocene}

The palaeodelta fans and sandy ridges are evidence of a higher lake level. The maximum altitude of their occurrence $1990 \mathrm{~m}$ at the northern extremity of the Rukwa depression) corresponds to the lowest altitude of the watershed between the Rukwa and Tanganyika drainage basins (between 969 and $980 \mathrm{~m}$ ). This suggests that at that the time of the high lake level, the water of the Rukwa Rift Basin was flowing out to Lake Tanganyika, via the Kinywangiri swamps and the Nkamba River.

The high lake stand in the closed East African lakes could be achieved by an increase in precipitation and/or a decrease in evaporation, both resulting from climatic changes (Haberyan and Hecky, 1987). In much of East Africa, arid conditions prevailed before $20,000 \mathrm{yr}$. BP, when most lake levels were low (e.g. Scholz and Rosendahl, 1988). The last major humid climatic phase in Central Africa is known to have occurred between 12,000 and $9000 \mathrm{yr}$. BP, maybe up until $7000 \mathrm{yr}$. BP in places. This is indicated by a high lake level in Lakes Victoria (Adamson et al., 1980) and Kivu (Haberyan and Kecky, 1987), by low sedimentation rates in Lakes Kivu and Tanganyika (Haberyan and Kecky, 1987) and by trace element analysis in the Nile Delta sediments (Hamroush and Stanley, 1990). Also in Lake Magadi (south Kenya), an Early Holocene wet phase corresponding to laminated clays and zeolites is ${ }^{14} \mathrm{C}$ dated to 9120 yr. BP (Butzer et al., 1972). Detailed sedimentological and geochemical analysis of two cores from Lake Magadi document a wet and high lake level between 12,000 and $10,000 \mathrm{yr}$. BP (Damnati and Taieb, 1995). For Lake Malawi, major recession had already occurred in 10,740 \pm 130 yr. BP (Owen et al., 1990; Finney and Johnson, 1991), although this lake is known to 
have a slightly different evolution than the lakes north of it.

The high lake level in Lake Rukwa might correspond to this Late Quaternary climatic optimum, between 12,000 and $9000 \mathrm{yr}$. BP. This is supported by a new ${ }^{14} \mathrm{C}$ age of $9615 \pm 95$ yr. BP, obtained on a charcoal sample taken from the highest terrace near Muze $11000 \mathrm{~m}$ a.s.l.; index 5 in Fig. 2). This result fits remarkably well with the ${ }^{14} \mathrm{C}$ age of $9740 \pm 140 \mathrm{yr}$. BP on a mollusc shell from a mollusc rich layer on top of the lacustrine sequence, south of Galula (Clark et al., 1970). From the description of Clark et al. (1970) and the observations made in this study, the elevation of the sampling site should be at $900-920 \mathrm{~m}$ a.s.l., not far from the Lake Rukwa high stand. This age may date the emergence of this area at that time, and the corresponding palaeolake level.

A high lake level in Lake Rukwa during 12,700 and $4400 \mathrm{yr}$. B.P. had already been inferred by Haberyan (1987) on the basis of fossil diatom assemblages in a $23.1 \mathrm{~m}$ sediment core from Lake Rukwa. Since then, Lake Rukwa dried out progressively and became a closed hydrological system. It has completely dried out at least three times since $3300 \mathrm{yr}$. B.P. (Talbot and Livingstone, 1989). In recent times, from 1740 to $1840 \mathrm{AD}$, Lake Rukwa was again completely dry (Owen et al., 1990). Since then, the surface occupied by the lake is progressively increasing, as shown by a compilation of lake contours from cartographic documents and satellite images (Fig. 2). The 1:120 000 geological maps of the Tanganyika territory, based on an aerophotographical survey made in 1950, show two isolated pools separated by a zone of seasonal flooding. The 1:50 000 topographical maps of Tanzania, based on a new aerophotographical survey in 1977, show a greater and unified lake. A Landsat MSS image taken in 1984 during the same season shows that the lake has continued to expand in the northern plain and near Ivuna. During the last field work in June-July 1994, it was observed that the contour of the lake is a little wider, mainly at both extremities where the floor of the depression is very flat.

\section{ACTIVE FAULTING}

The tectonic activity of the Rukwa-Mbeya region is demonstrated by its high seismicity, often characterised by unusually deep hypocentres of 15-35 km (Camelbeeck and Iranga, 1996) and by field observations made during the geological mapping of this area. In this section evidence is examined for possible modern tectonic movements along the major rift faults: the Lupa, Mbeya Range-Galula, the Ufipa and the Kanda Faults (Figs 1 and 2).

The Early Holocene lacustrine terraces mentioned above will be used as a stratigraphical reference to evaluate the recent tectonic activity along the Lupa and Ufipa Faults. The Mbeya Range-Galula Fault will be investigated using morphostructural and microstructural observations, and the results of a high resolution seismic survey made by Cermicola et al. (1996) in the southern part of Lake Rukwa.

In several places, microstructural data were collected on minor faults with slip indicators, conjugated pairs of joints and single joints. They were used to identify the kinematics of faulting and to differentiate between normal and strikeslip faulting. Additionally, they were inverted to determine the reduced palaeostress tensors following the method of Angelier and Mechler (1977) and Angelier (1989), using the TENSOR program (Delvaux, 1993b). Although palaeostress reconstruction is not the main topic of this paper, the palaeostress results represent additional constraints for the tectonic interpretation. More details of this method are provided in Delvaux et al. (in press).

\section{Lupa Fault}

The Lupa Fault separates the Rukwa Rift Basin from the Tanzanian Craton and the Lupa block (Fig. 1), topped by the African I lateritic morphological surface of Late Miocene age (King, 1963). The fault appears relatively rectilinear, but in detail it is composed of several curved segments (Fig. 3). It is associated with a well expressed morphological scarp up to $200 \mathrm{~m}$ high. To the southeast the scarp progressively fades out and disappears near Mbeya. In between, the Lupa Fault splays in several segments also running inside the Lupa block, and some of them continue into the Usangu depression. The seismic activity recorded by the Mbeya seismic station is precisely concentrated along some of these lateral branches (Delvaux and Hanon, 1993).

The structure of the Lupa Fault itself is made of a series of thin (1-5 m), steeply inclined (45-

Figure 7. Lupa Fault scarp near Mkwajuni: fault kinematics and stress tensor reconstruction from data of the Luika River falls (index 1 in Figs 2 and 3). Stereograms (Schmidt net, lower hemisphere) with traces of fault planes, observed slip lines and slip senses; histogram of observed slip-theoretical shear deviations for each fault plane and stress map symbols. Rose diagrams of the dip and strike of fault planes and joints, and inclination and azimuth of slip lines. 


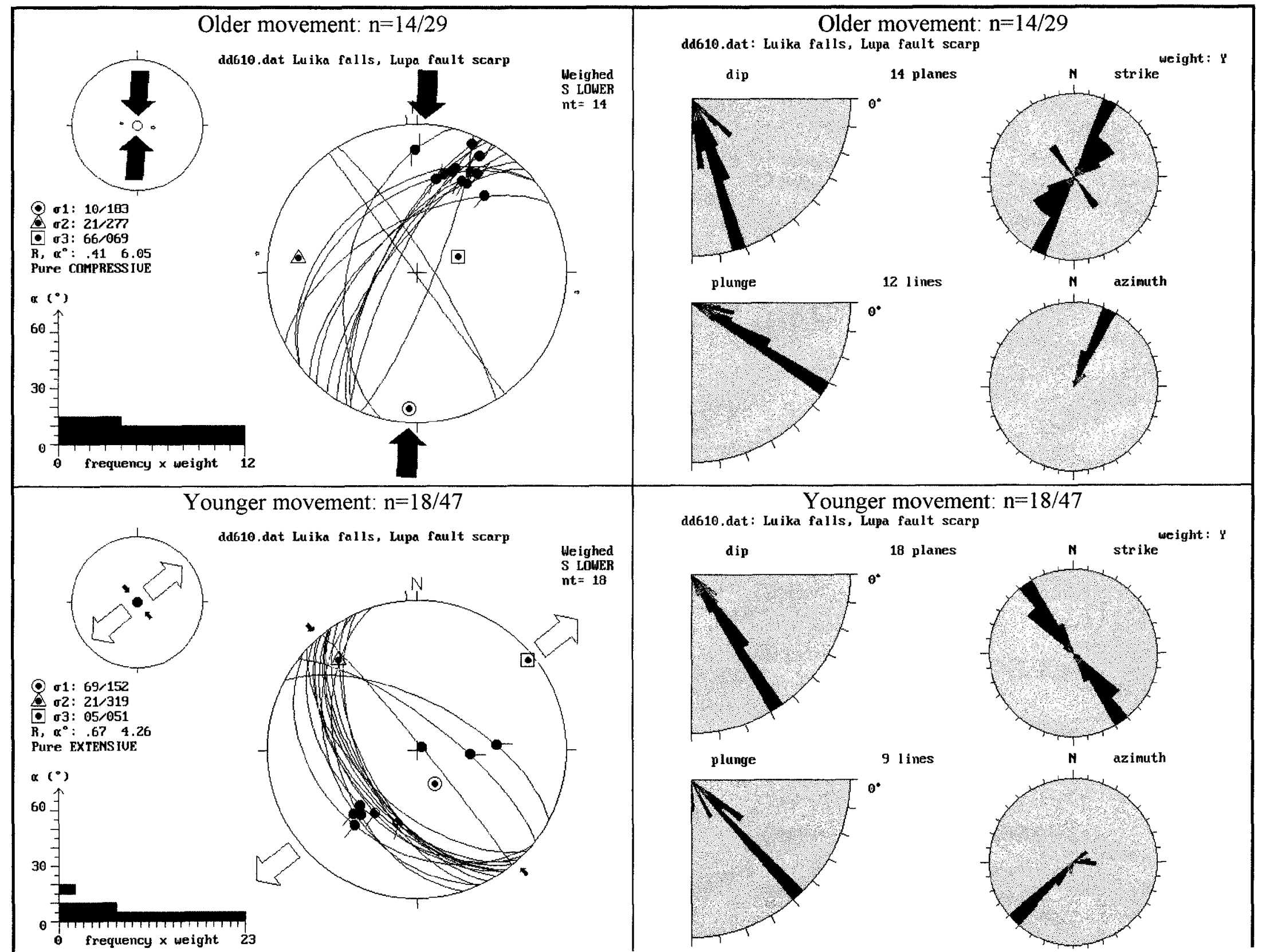




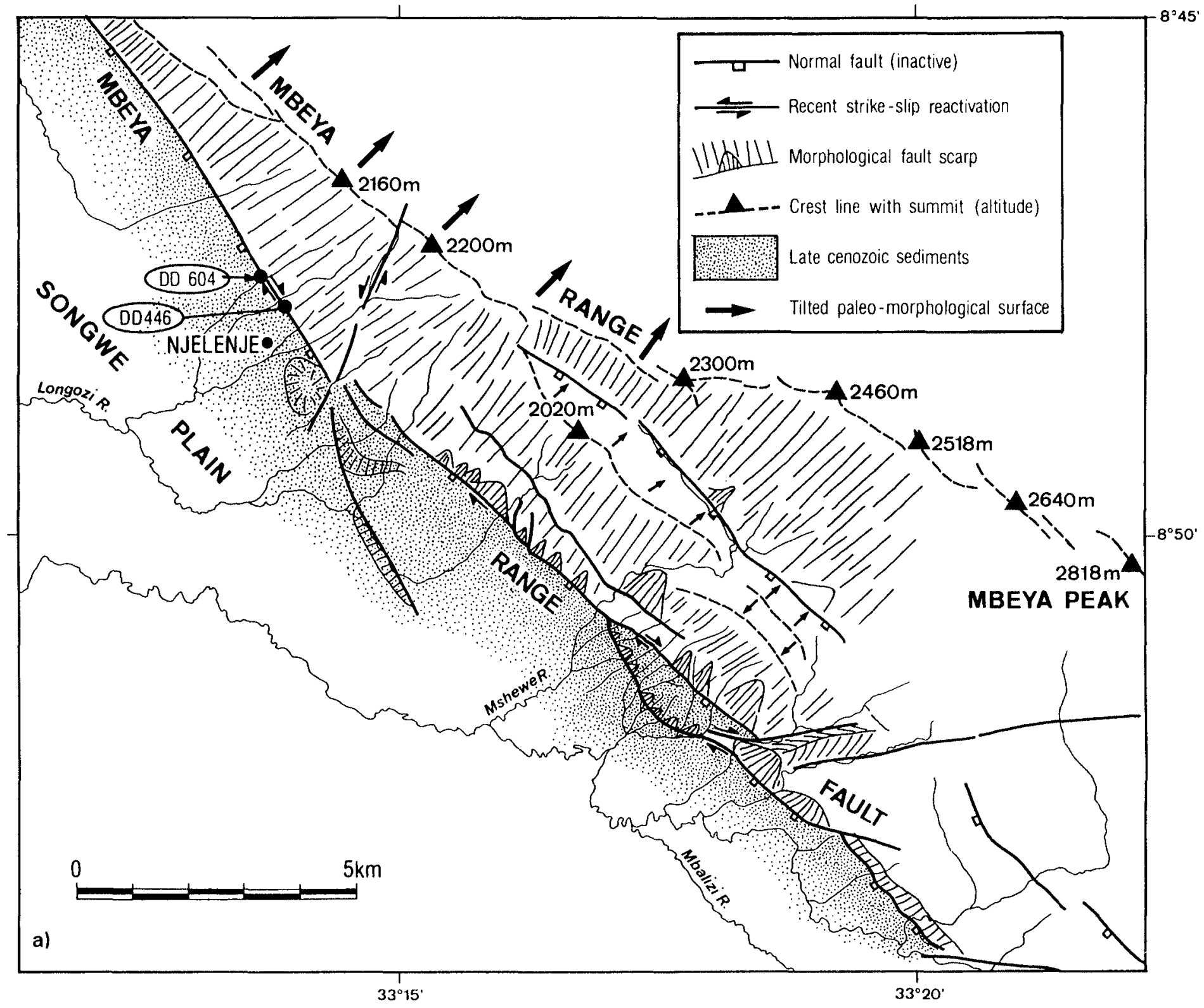

Figure 8. Mbeya Fault near Njelenje (index 9 in Fig. 2). (a) Morphostructural map with the location of the palaeostress sites. 


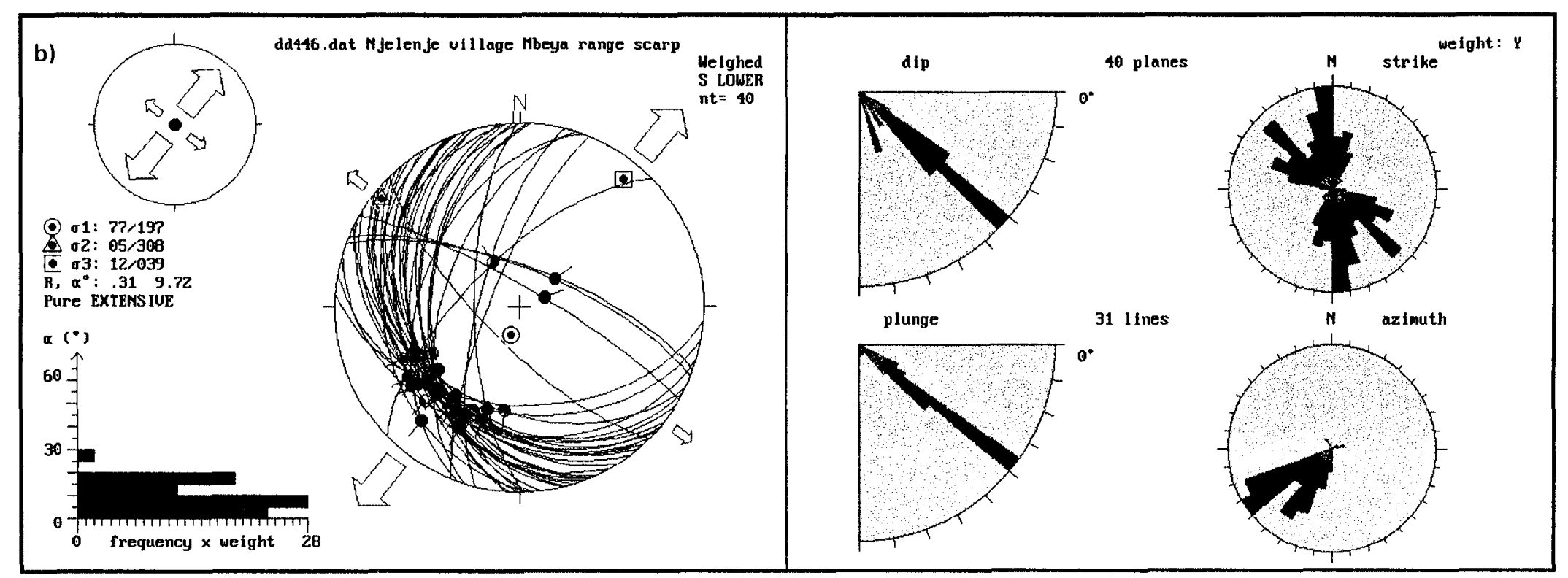

Figure 8. continued. (b) Fault kinematics and stress tensor reconstruction for site DD446: normal faulting only (location in a). 


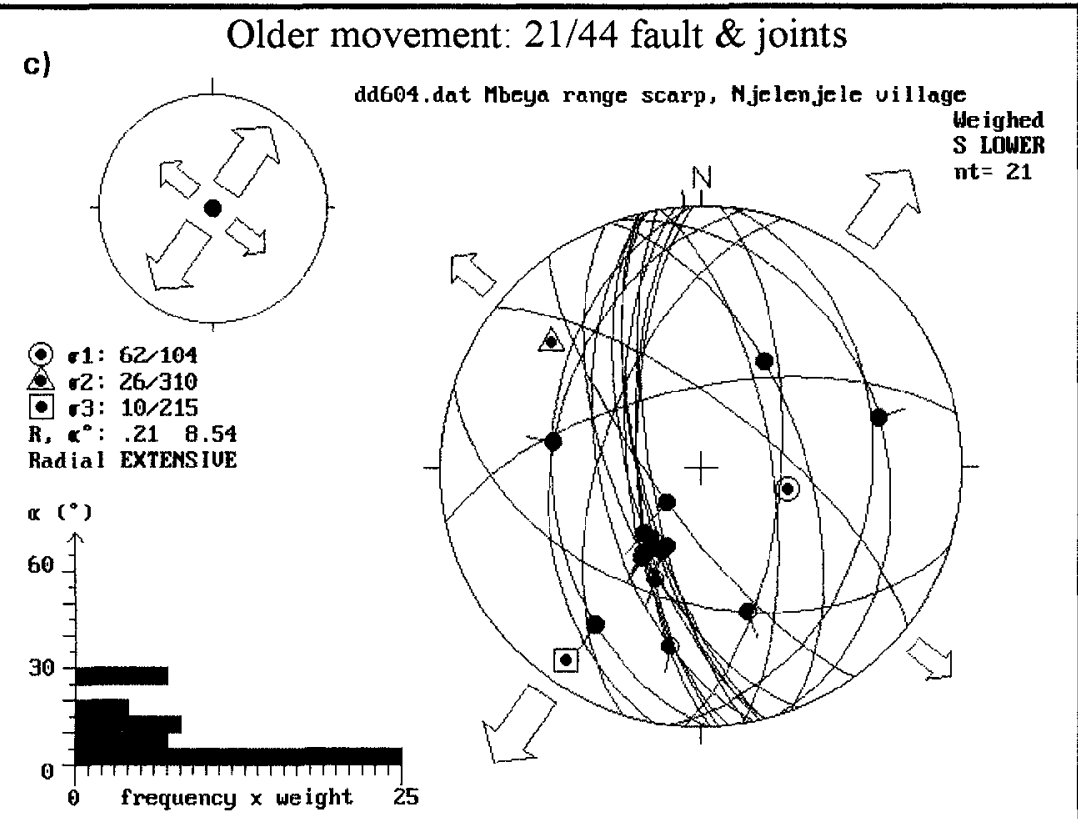

Younger movement: 13/44 faults \& joints

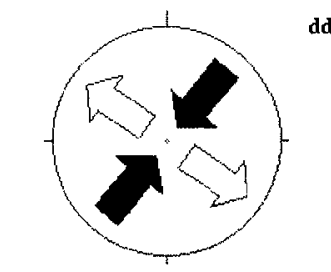

(1: $23 / 219$

r2: 65/015

r3: 09/125

R, $K^{\circ}: .46 \quad 7.44$
Pure STR IKE-SL IP

a $\left({ }^{\circ}\right)$
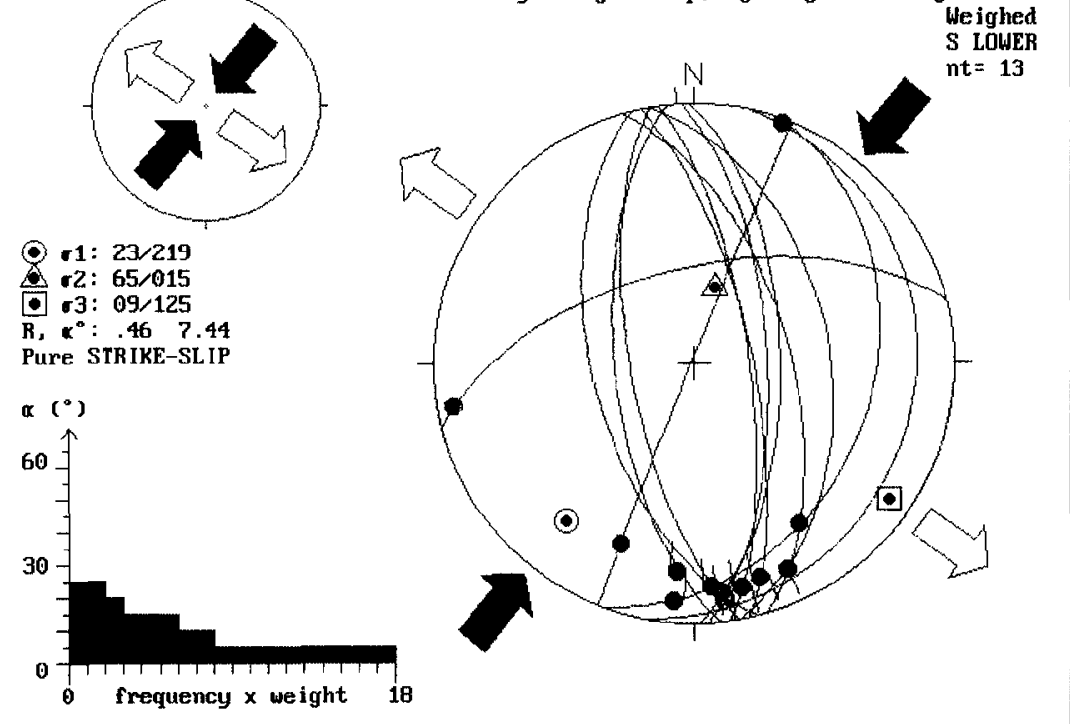

Older movement: $21 / 44$ fault $\&$ joints dd604.dat: Mheya range scarp, Mjelen je le village

dip 21 planes N strike weight: $Y$

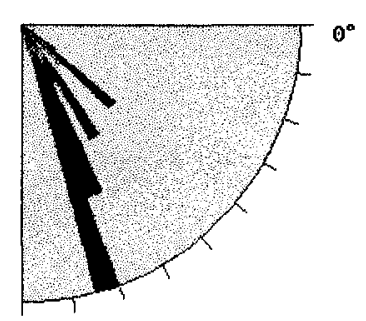

plunge

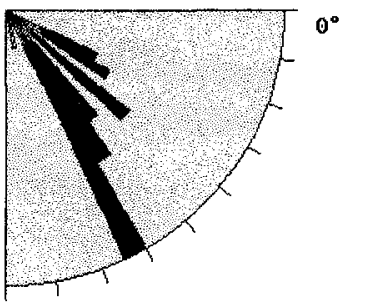

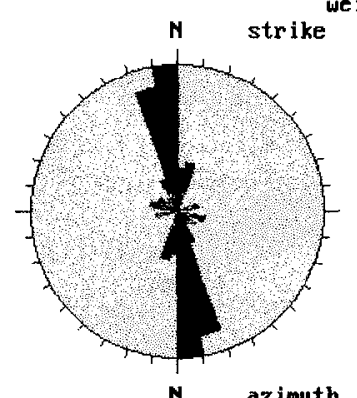

15 lines

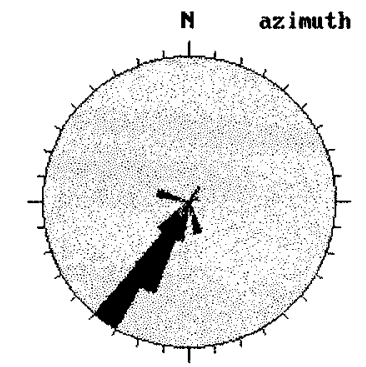

Younger movement: $13 / 44$ faults \& joints dd604.dat: Mbeya range scarp, Mjelenjele village

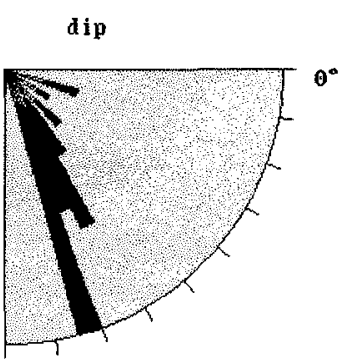

plunge

13 planes

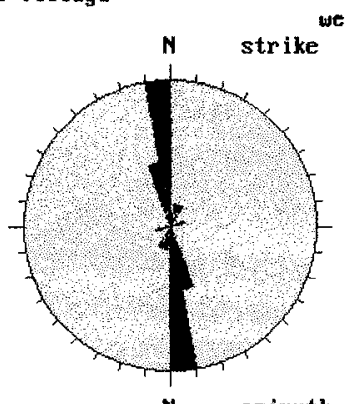

13 lines
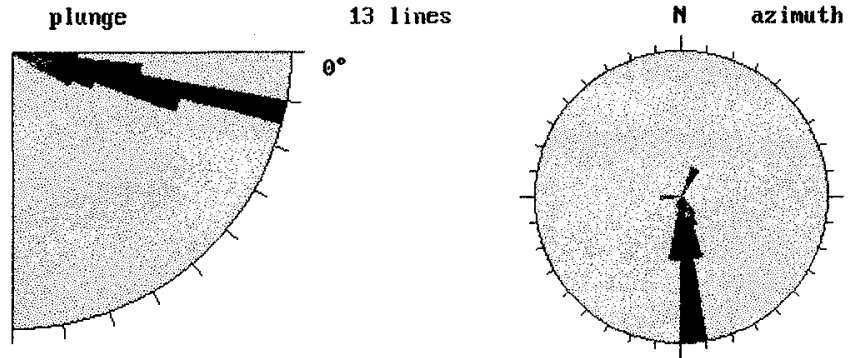

$0^{\circ}$

weight: Y 
$65^{\circ}$ ) tectonic slices of basement rock (massive granite in the investigated area). The few slip lines observed on these slices provide dip-slip to oblique-slip directions. The inclination of the fault plane and the presence of curved fault segments are typical for normal faulting in an extensional stress regime (e.g. Stewart and Hancock, 1991). In addition, the tectonic slices cut older minor fault planes with well expressed slip lines, indicating a dominant strike-slip movement (Fig. 7). These observations are in accordance with the succession of (1) strikeslip and (2) normal faulting, described by Tiercelin et al. (1988) for the Lupa Fault.

Using the Late Quaternary lacustrine terraces as a reference, the major normal faulting along the Lupa Fault seems to have occurred before the Early Holocene. The observed terraces lie undisturbed against the major fault scarp. Limited tectonic movement might have occurred at the foot of the scarp since the deposition of the terraces, but more detailed analysis of air photographs, field geology, topographical measurements and trenching are necessary to solve this issue. In any case, examination of available air photographs reveals no evidence for large recent offsets. In particular, horizontal displacements can be excluded for the Late Quaternary. No offset of drainage, no pull-aparts or push-ups, typical of strike-slip faults (e.g. Sylvester, 1988) are evident. This is especially the case near Saza Falls, where the fault scarp presents a series of curved sections without perturbations of the sedimentary layers resting on it. It is clear that no important tectonic activity occurred along this portion of the Lupa Fault after the deposition of the alluvial fans into the former lake with higher water level. However, it cannot be ruled out that some recent movements may have occurred on some still undetected fault inside the graben. A shift of faulting with time towards the centre of the depression is commonly observed in normal faulting (e.g. Stewart and Hancock, 1991), or in the case of kinematic inversion (e.g. Ring et al., 1992).

\section{Ufipa Escarpment}

The Ufipa Escarpment is up to $1000 \mathrm{~m}$ high above the lake level and bounds the southwestern side of the Rukwa Rift. The latter is comparable to the Lupa Fault, but less continuous (deep valleys cut through the range front) and rectilinear. Based on seismic reflection profiles (e.g. Morley et al., 1992; Kilembe and Rosendahl, 1992), the total vertical offset of the Ufipa Fault $(2-4 \mathrm{~km})$ is less than that of the Lupa Fault $(4-11 \mathrm{~km})$, but the total vertical relief difference is much greater $(1000-1200 \mathrm{~m}$ ) than that of the Lupa scarp (100-200 m). As for the Lupa scarp, field observations and aerophotographical interpretation reveal the absence of significant vertical or horizontal movements displacing the Late Quaternary deposits along the Ufipa Fault scarp.

\section{Mbeya Range-Galula Fault Zone}

The Mbeya Range Fault (Figs 2 and 9a) runs along the southwestern foot of the northwestsoutheast trending Mbeya Range. It is an uplifted basement block protruding the main Lupa Escarpment between the Rukwa Rift Basin and Mbeya. The summit of the Mbeya Range (2818 $\mathrm{m}$ a.s.l.) lies above the mid-Miocene reference surface of the African I laterite peneplain, which has an elevation of 1300-1600 $\mathrm{m}$ a.s.l. in the adjacent Lupa block and $1600 \mathrm{~m}$ a.s.l. in the Mbozi block. The uplift of the Mbeya Range caused the narrowing of the Rukwa depression at its southeastern extremity, which is thereby restricted to the $10 \mathrm{~km}$-wide Songwe-Rukwa Valley.

The Mbeya Range appears to be an uplifted basement block tilted to the northwest. On air photographs, the northeastern flank looks like a strongly tilted remnant of the African I peneplain (Fig. 8a). The southwestern flank is bounded by a weakly inclined normal fault with dip-slip slickensides (Fig. 8b). This flank corresponds therefore to a major fault scarp in which intermediate steps are recognised (Fig. 8a).

The foothill of the Mbeya Range scarp along the southwestern flank has steep triangular spurs which, although partly following a pre-existing structural grain, on the whole strongly suggest a recent rejuvenation of the range front (Fig. 8a). A survey conducted in the Njelenje area at the contact between the basement and Quaternary deposits did not reveal any evidence of recent tectonic movement, however the area is covered by thick vegetation and agricultural activities may shroud some critical exposures. The steep slope along the faceted spurs, almost free scarp faces at their base, and the general morphology with back-tilted faulted Quaternary surfaces, suggest some recent movements in the area. The presence of push-up slices of the

Figure 8. continued. (c) Fault kinematics and stress tensor reconstruction for site DD604: older normal faulting and younger strike-slip faulting (location in a). 
basement rocks covered by Quaternary deposits in front of the main scarp, secondary obliquetrending faults and displaced river valleys are suggestive of a strike-slip component. A small quarry excavated in a limonitised rock along the fault plane (index 9 in Fig. 2) shows the presence of two generations of minor faults: a dip-slip and a strike-slip system with right-lateral movement along the trend of the Mbeya Range Fault (Fig. $8 \mathrm{c}$ ). Cross-cutting relationships allow the strike-slip system to be defined as the youngest.

In the valley floor, in the continuation of the Mbeya Range Fault, minor faults with slip indicators and joints were observed in the Late Quaternary volcanic, lacustrine and fluvial gravel beds in the canyons of the Ipwizi River (index 11 in Fig. 2; Fig. 9a) and in one tributary of the Songwe River (index 10 in Fig. 2; Fig. 9b). These observations suggest a northwestern continuation of the Mbeya Range Fault Zone, at least up to the Galula Village.

The Mbeya Range-Galula Fault Zone probably continues beneath the lake along the same trend. This is ascertained by a high resolution seismic survey in the southern half of Lake Rukwa, recording the upper $200 \mathrm{~m}$ of sediment (Cermicola et al., 1996). A series of steeply dipping faults have affected the uppermost reflectors and are typically syndepositional with the youngest lake sediments (Cermicola et al., 1996).

In the multichannel seismics carried out by AMOCO in the same area, Morley et al. (1992) demonstrates the existence of an important fault line that affects most of the sediment infill in a positive flower structure. However, the multichannel seismics probably did not record the upper layer. The faults seen on the high resolution seismics might well be branched to the deeper flower structures.

The palaeostress tensors obtained for the three sites along the Mbeya Range-Galula Fault Zone (Njelenje, Ipwizi River and Galula) display both principal compression $\left(\sigma_{1}\right)$ and extension $\left(\sigma_{3}\right)$ horizontal stress axes, indicating a prevalent strike-slip style of deformation. The $\mathrm{S}_{H \max }\left(\sigma_{1}\right)$ axes trend north-northeast - southsouthwest, ranging from $N O 5^{\circ} \mathrm{E}$ to $\mathrm{N} 39^{\circ} \mathrm{E}$ and the $\mathrm{S}_{\mathrm{Hmin}}\left(\sigma_{3}\right)$ axes trend west-northwest - eastsoutheast, ranging from $\mathrm{NO} 96^{\circ} \mathrm{E}$ to $\mathrm{N} 125^{\circ} \mathrm{E}$. The relative succession of (i) normal faulting and (ii) dextral strike-slip faulting observed in Njelenje, at the foot of the Mbeya Range, is in full agreement with the previous results from palaeostress investigations for the Late
Quaternary period in the Mbeya area (Delvaux et al., 1992).

\section{Kanda Fault}

The Kanda Fault (Figs 1 and 2) appears to be the most active structure in the Rukwa area. It runs almost continuously for about $180 \mathrm{~km}$, from near Tunduma to north of Sumbawanga. The Kanda Fault dissects the Ufipa Plateau along its trend, between the Rukwa and Tanganyika Rift Basins. The height of the free scarp face decreases progressively towards the northwest, from about $50 \mathrm{~m}$ near Mpui to a few metres near Sumbawanga. In some segments the faulting appears to be distributed on several subparallel scarps that look younger towards the valley axis. Elsewhere, the faulting is concentrated on a single plane. It strikes generally to the northwest-southeast and dips to the northeast, displacing the laterite surface related to the African I mid-Miocene peneplain of King (1963). On its hangingwall side a large "Mbuga" (swamp) corridor forms a perched depression at the top of the Ufipa Plateau. Two other similar faults are known further west: the Mkunda and Mwimbi Faults (Fig. 2). They all affect the drainage pattern profoundly.

The Kanda Fault is hosted either in the basement gneisses or in the Karoo sediments. To the north it is linked with the fault structure that affects the Namwele coal field. The Kanda Fault is described by van Loenen and Kennerley (1962) as reactivating an ancient structural line. Microstructural indicators found along the Kanda Fault (Fig. 10a) and the in Namwele coal field near Sumbawanga, the structure of the coal field itself (McConnell, 1947) and the presence of isolated lenses of Karoo sediments along the Kanda Fault near Sumbawanga all suggest that an important right-lateral strike-slip movement occurred along this line, after the deposition of the Karoo beds (Late Carboniferous-Permian). The presence of the laterite surface truncating all these structures constrains the age of the strike-slip activity as pre-Middle Miocene. It is likely that this movement took place before or at the beginning of the Late Jurassic-Early Cretaceous phase of denudation revealed by van der Beek et al. (1998) by apatite fission track thermochronology. Recent activity along the Kanda Fault is dominantly dip-slip, displacing the laterite surface.

An important section across the fault zone is exposed along a trench of the road that climbs the fault scarp near Kaengesa (index 8 in Fig. 2; Fig. 10b). The difference in elevation 
Older movement: $28 / 104$ faults

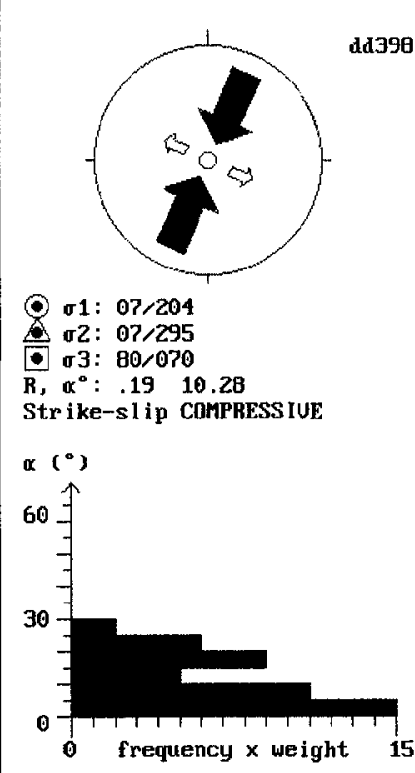

Younger movement: 42/104 faults

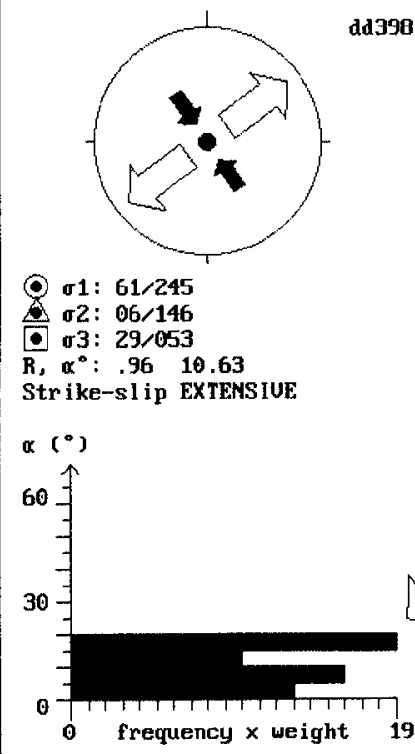

Older movement: $28 / 104$ faults dd398.dat: Kanda fault, Sumbawanga (1992-1994)

dip 28 planes

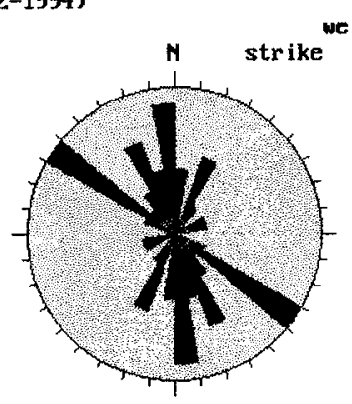

plunge

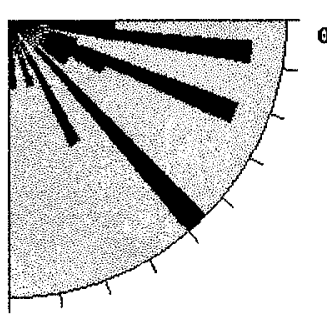

weight: $Y$

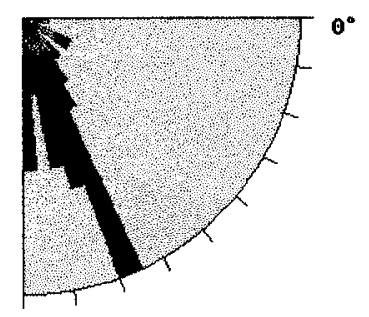

25 lines

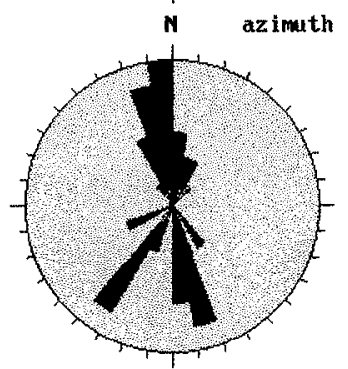

Younger movement: 42/104 faults dd398.dat: Kanda fault, Sumbawanga (1992-1994)

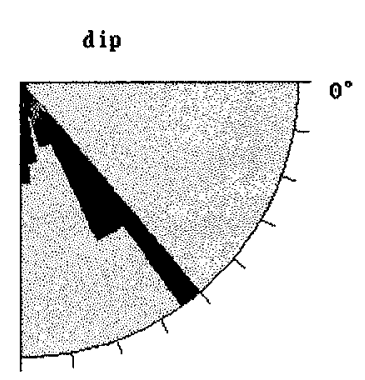

42 planes

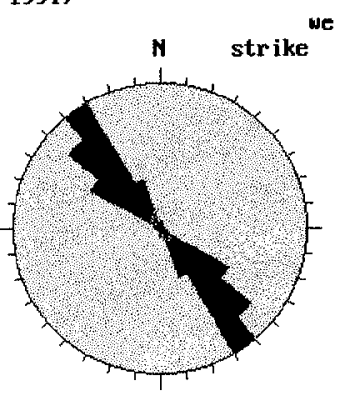

plunge

25 lines
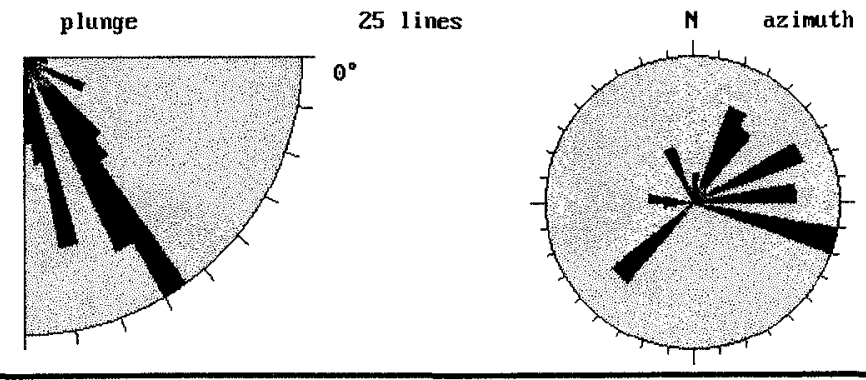

weight: $Y$

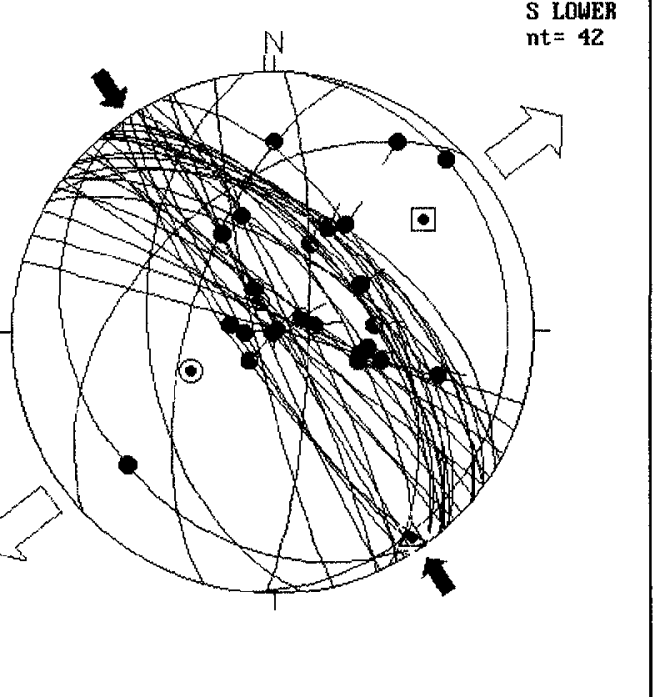




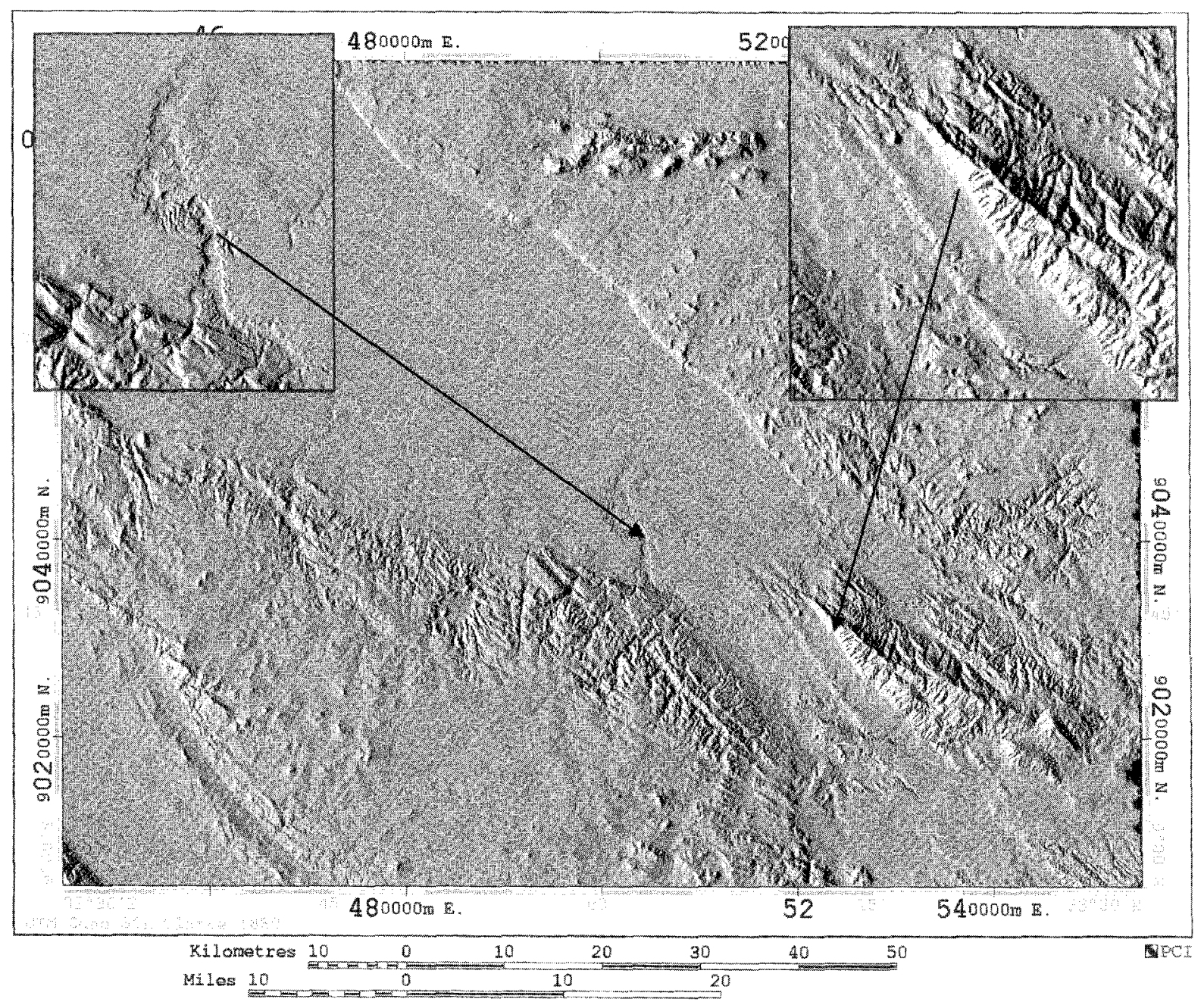

Figure 11. Digital shaded topographical model of the southern extremity of the Rukwa Depression, computed from digitised 1:50 000 topographical maps.

between the surface topping the footwall and the pounding area in front of the scarp is about $30 \mathrm{~m}$. Several minor fault planes parallel the main escarpment with one displacing the top of the basement by $1.5 \mathrm{~m}$ of vertical offset. A weathered mylonitic gneiss, topped by a thick soil, is found opposite fluvial and lacustrine deposits dragged and tilted near the fault. A sample of charcoal collected in the fluvial deposit, just on the footwall of the scarp, yielded a radiocarbon age of $8340 \pm 700$ yr. BP (Vittori et al., 1997). This is a maximum age for the major event that caused this dislocation. It should not be very far from the maximum age, since this sample comes from the first sediments deposited after the escarpment formation.
At the same location a few metres below, a layer of black organic clay covers the footwall basement. It yielded a radiocarbon age of 13,600 \pm 1240 yr. BP (Vittori et al., 1997). The fluvial deposit above the fault scarp also contains debris of a similar organic rich black clay, suggesting that this layer was originally continuous and disrupted by the $8340 \pm 700 \mathrm{yr}$. BP event. These Late Pleistocene-Holocene deposits now hang more than $15 \mathrm{~m}$ above the present valley floor, suggesting a Holocene slip rate of more than $1.0 \mathrm{~mm} \mathrm{a}^{-1}$.

Due to its high rate of activity in the recent times, the Kanda Fault may have produced the 1910 Rukwa M 7.4 earthquake, whose instrumental epicentre was located very near the fault (Ambraseys, 1991). The Kanda Fault is then

Figure 10. Kanda Fault. Fault kinematics and stress tensor reconstruction near Sumbawanga (site DD393, index 7 in Fig. 2): older transpressional faulting and younger transtensional faulting. 


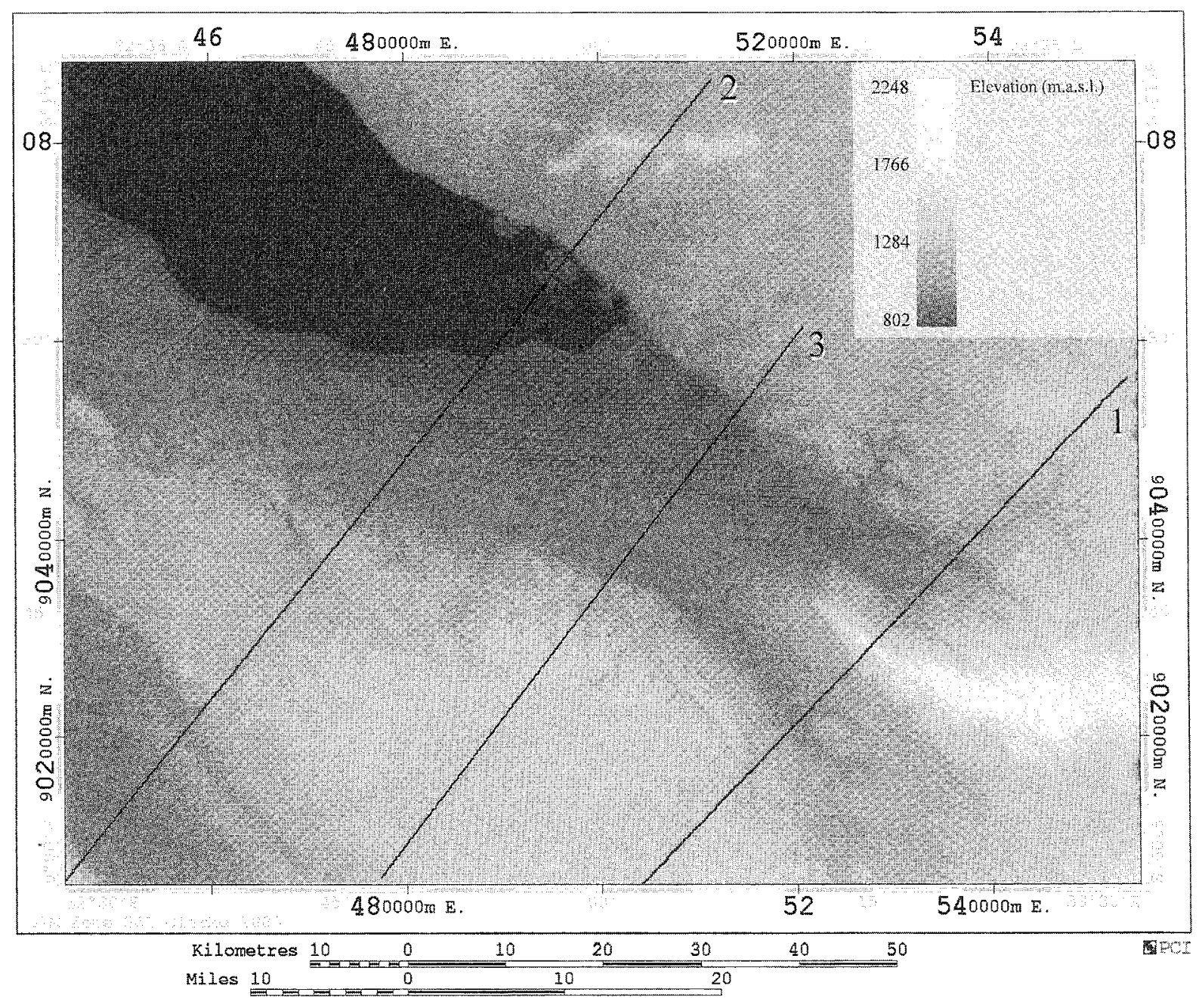

Figure 12. (a) Same digital topographical model as in Fig. 11. Grey intensity is as a function of altitude. Lines 1-3 locate the topographical sections of $b$.

comparable with the $100 \mathrm{~km}$ long BililaMtakataka normal fault in southern Malawi, along which occurred the march $9(M=5.7)$ and March $10(M=6.1)$ earthquakes (Jackson and Blenkinshop, 1997). More details on the recent activity of the Kanda Fault are provided in Vittori et al. (1997).

\section{VERTICAL MOVEMENT AND REGIONAL TILTING}

The elevation of the highest lacustrine terraces and sandy ridges at different locations around the Rukwa depression is not constant. Preliminary altitude measurements, using an altimeter calibrated to the lake level, reveal that the terraces along the central part of the Lupa Fault, at the northeastern side of the depression (840-860 $\mathrm{m}$ a.s.I.), are more depressed than the terraces against the Ufipa Fault, on the opposite side (up to $1000 \mathrm{~m}$ ). The upper terraces along the Lupa Fault are more elevated towards its southeastern termination, in the direction of the Rungwe Volcanic Province (900-950 m) and at the northern termination of the Rukwa depression (llyandi sand ridge: $980-998 \mathrm{~m}$ ). This indicates that the northeastern central part of the Rukwa depression is presently subsiding relative to the rest of the depression. This interpretation supposes that all the highest terraces at each site and the highest sandy ridges were formed at the altitude of the outflow sill of Lake Rukwa during the last humid period, in the Early Holocene. However, some terraces may have not been deposited at this time and others may have been entirely removed by erosion, depending on local conditions. In the absence of the precise stratigraphy and morphology of the terraces, stratigraphical markers and systematic ${ }^{14} \mathrm{C}$ dating, it is necessary to look for other clues to the recent differential vertical movements. 


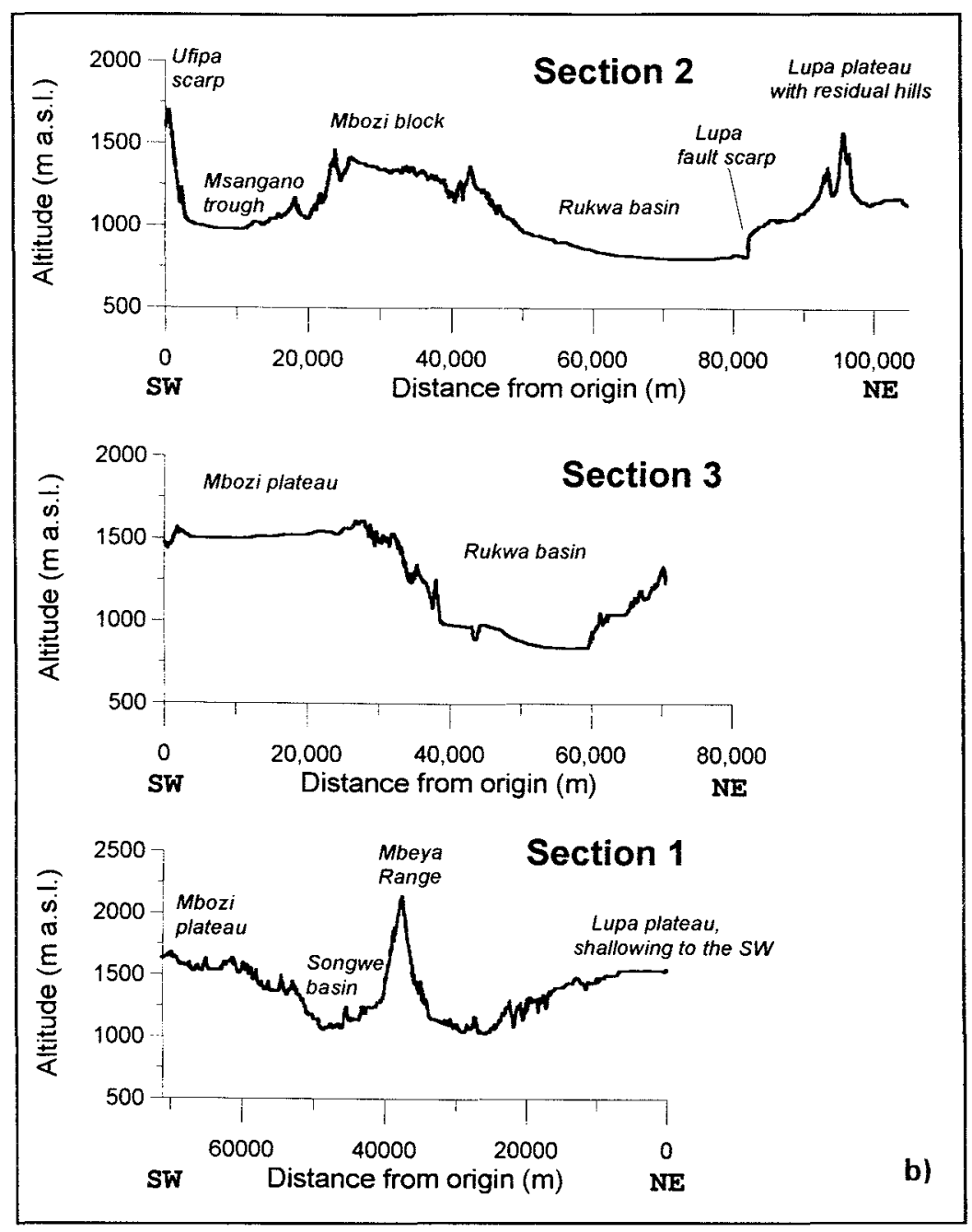

Figure 12. continued. (b) Topographical sections (location in a).

Evidence for the northeastward tilting of the southern part of the Rukwa Rift Basin is best provided by the morphology and asymmetry of the basin floor topography (Fig. 12). The northeastern side of the Rukwa depression is mostly occupied by water and swamps, with the lake extending very close to the Lupa Escarpment. The southwestern side of the depression is a dry plain, with deeply incised rivers in the Late Quaternary sediments. The Ipwizi, and Momba Rivers are incised into the Rukwa lake beds for more than $20 \mathrm{~m}$, and the Songwe River up to $80 \mathrm{~m}$ (Fig. 11).

The Late Quaternary regional tilting of the Rukwa Depression is in accordance with longterm differential vertical movements between the Ufipa Plateau and the Lupa Plateau, with reference to the African I (mid-Miocene) laterite peneplain. In the Lupa Plateau this surface is sloping progressively westwards, from $1570 \mathrm{~m}$ near Chunya, $25-30 \mathrm{~km}$ west from the Lupa
Fault scarp, to $900-1000 \mathrm{~m}$ a.s.l. near the fault (Fig. 12b). Residual inselbergs from an older peneplain surface range from $1725 \mathrm{~m}$ to 1400 $\mathrm{m}$ a.s.I. In the Ufipa Plateau, the laterite African I surface lies at 1800-1900 m a.s.l. at Sumbawanga near the Ufipa Escarpment, and decreases westwards to $1500 \mathrm{~m}$ a.s.l. at Namanyere towards Lake Tanganyika.

At the southern end of the Rukwa Depression, a broad zone of doming has developed in the vicinity of the Mbeya Range uplift. The dome coincides with the Mbeya Range-Galula zone of active strike-slip dislocation. This doming causes an uplift in the axial part of the depression. This has caused divergent tilting of the former lake floor, with apparent deepening towards the Lupa and Ufipa Border Faults. This is particularly well illustrated by the northeast flowing Ipwizi River, which has deeply incised into the Quaternary sediments (Fig. 11). 
Preliminary analysis of the high resolution seismic profiles in Lake Rukwa (Cermicola et al., 1996) suggests that sedimentation in the southern part of the lake is controlled by a combination of subsidence towards the Lupa Border Fault and uplift in the central part of the depression. The upper sedimentary layers in the central part of the depression are strongly affected by faulting and associated deformation, while they are less disturbed and progressively thicker towards the northeastern margin. Recent subsidence associated with normal faulting along the Lupa Border Fault can be invoked to explain the progressive thickening of the sedimentary layers towards the northeast. However, the lack of marked recent tectonic activity along this border fault, and the presence of the active Mbeya Range-Galula dislocation zone in the axial part of the depression, favour the idea that the tectonic factor controlling the sedimentation is a combination of axial doming (uplift) linked to the Mbeya Range-Galula dislocation zone and subsidence in the area of the Lupa Border Fault in the region of GalulaMkwajuni. This means that the basin floor and rift shoulder subside together, restricting fault movement between them.

This differential movement can be related to a combination of large scale tilting of the central part of the depression towards the northeast and general uplift of the southeastern extremity of the depression. The latter is in agreement with the Quaternary uplift centred on the Rungwe Volcanic Province (Delvaux and Hanon, 1993), whereas the former is similar to the tilting of the Kyela plain at the northern extremity of the Malawi (Nyasa) Depression (Delvaux and Hanon, 1993). It is also revealed by morphostructural and high resolution seismic investigations (de Vos, 1994).

This asymmetric subsidence may also reflect a possible local post-rift subsidence of this region. Post-rift subsidence may be driven by an isostatic response to sedimentary loading and by thermal relaxation, contraction of the lithosphere and compressional intraplate stresses (Cloetingh and Kooi, 1992; Ziegler, 1996). In fact, most of the subsided area corresponds to the thickest Cenozoic sedimentary accumulation, up to $7 \mathrm{~km}$ according to Morley et al. (1992). Moreover, the region has been submitted to compressive intraplate stresses since the Middle Pleistocene (Delvaux et al., 1993). However, more investigations and kinematic modelling are necessary to understand the causes of these vertical movements.

\section{SYNTHESIS AND CONCLUSIONS}

Results of morphostructural investigation reveal that the major border faults of the Rukwa Rift Basin underwent moderate tectonic activity in the Late Pleistocene-Holocene. Observation of the palaeolacustrine deltas and sandy ridges along the margin of the Rukwa Depression allows the recognition of both climatic and tectonic effects.

Long term variations of water level and areal extent of the lake are indicated by palaeolacustrine terraces 60 to $170 \mathrm{~m}$ above the present-day level of the lake and up to $115 \mathrm{~km}$ north of its present northern shore. Short term fluctuations of the lake surface are recorded by historical and cartographic documents and satellite images. The higher level of terraces and sandy ridges corresponds to the altitude of the watershed, over which water from Lake Rukwa was outflowing into Lake Tanganyika during the last humid period. The high lake level in Lake Rukwa is preliminarily dated as Early Holocene.

The present altitude difference of the highest terraces in several locations around the Rukwa Depression indicates that substantial differential tectonic movement occurred in the Holocene. The terraces along the escarpment of the Lupa Border Fault, on the northeastern side, are more depressed than the ones along the escarpment of the Ufipa Border Fault on the southeastern side. This demonstrates an active northeastward tilting of the entire depression, including both the rift shoulder and the adjacent depression floor. Along trend, the terraces against the Lupa Border Fault are also more depressed in the centre of the depression than in both extremities. This may reflect the doming associated with the Late Quaternary activity of the Rungwe volcanic centre.

The kinematics of faulting along the major faults of the Rukwa Rift Basin are more complex than previously thought. An earlier episode of strike-slip faulting can be seen from slickensides present in the footwall of the Lupa Border Fault, and along the Kanda Fault in the Ufipa Plateau. Strike-slip faulting along the Kanda Fault displaced the Karoo sediments of the Namwele coal field, but did not affect the mid-Miocene laterite crust of the Ufipa Plateau. Along the Lupa Border Fault, normal faulting occurred later than strike-slip faulting and seems to be related to the deposition of the Late Cenozoic lake beds. The Mbeya Range appears to be a strongly uplifted and tilted block formed by asymmetric normal faulting. The normal fault system was reactivated in a right-lateral way in recent times. 
In the Late Quaternary, both the Lupa and Ufipa Fault scarps appear to be weakly active. Geomorphology, air photographs and field work have failed to prove the presence of any recent movement in the Late Quaternary. In the southern extremity of the Rukwa Rift Basin, an axial zone of active deformation can be observed in Landsat (TM) imagery, field work and high resolution seismic profiles in the lake itself. It corresponds to a right-lateral northwest trending strike-slip fault system, disrupting the Quaternary lake beds in prolongation of the Mbeya Range Fault. On the Ufipa rift shoulder, the Kanda Fault, together with the Mkunda and Mwimbi Faults, form an active normal fault system. Movement along the former may have caused the M 7.4 Rukwa earthquake of 13 December 1910.

In conclusion, the major border faults seem inactive or weakly active and the brittle deformation is transferred to the centre of the depression (Mbeya Range-Galula Fault Zone) and to the southwestern rift flank (Kanda Fault). The Late Quaternary tectonics of the Rukwa region is characterised by a complex combination of strikeslip and normal movements between the Mbeya Range-Galula and the Kanda Fault Zones. Active deformation is also expressed by regional tilting of the whole rift depression and the doming associated with the Rungwe volcanic activity.

Besides a marked climatic control of the lake water level fluctuation and sedimentation, the sediment transfer was and is strongly controlled by tectonic activity. Vertical differential tectonic movements control the location of the depocentres and uplifted parts of the basin floor. In consequence, the Late Quaternary sedimentation and lake level in the Rukwa Rift Basin are controlled, besides the obvious climatic factors, by active tectonics.

\section{ACKNOWLEDGEMENTS}

This work is a contribution to the RUKWA Project "Investigation of the sediments of Lake Rukwa (Tanzania): A clue for reconstructing the south equatorial climate during the last 130,000 years" funded by the EEC, DG XII Environment Programme, Area 1.1. Natural Climatic Change, co-ordinated by $\mathrm{M}$. Taieb and initiated by $\mathrm{J}$. Klerkx. This project received the support of the following Tanzanian institutions: Ministry of Water, Energy and Minerals (S. Bugaisa), MADINI (P. Kenyunko) and TPDC (Y.S. Mwalyego). This paper benefitted from the comments and suggestions of $H$. Wopfner and $H$. Dypvik.
This is also a contribution to projects IGCP400 "Geodynamics of Continental Rifting" and INTAS 93-134 "Continental Rift Tectonics and Sedimentary Basin Evolution".

\section{REFERENCES}

Adamson, D. A., Gasse, F., Street, F. A. and Williams, M. A. J. 1980. Late Quaternary history of the Nile. Nature 288, 50-55

Ambraseys, N. N. 1991. The Rukwa earthquake of 13 December 1910 in East Africa. Terra Nova 3, 202-211.

Ambraseys, N. N. and Adams, R. D. 1991. Reappraisal of major African earthquakes, south of $20^{\circ} \mathrm{N}, 1900-1930$. Natural Hazards 4, 389-419.

Angelier, J. 1989. From orientation to magnitudes in paleostress determinations using fault slip data. Journal Structural Geology 11, 37-50.

Angelier, J. et Mechler, P. 1977. Sur une méthode graphique de recherche des contraintes principales également utilisable en tectonique et en seismologie : la méthode des dièdres droits. Société géologique France Bulletin $7 /$ 19, 1309-1318.

Butzer, K. W., Isaac, G. L., Richardson, J. L. and WhashbournKamau, C. 1972. Radiocarbon dating of East-African lake levels. Science 175, 1069-1076.

Camelbeeck, T. 1992. Seismic activity in Southern Rukwa with data from Panda Hill station (September-November 1991). UNESCO Newsletter Geology for Economic Development 9, 183-194

Camelbeeck, T. and Iranga, M. D. 1996. Deep crustal earthquakes and active faults along the Rukwa trough, Eastern Africa. Geophysical Journal International 124 612-630.

Cermicola, S., Vanhauwaert, P., Kilembe, E. and de Batist, M. 1996. High-resolution reflection seismic investigation of Lake Rukwa. Natural Climatic Change, Rukwa project Progress report (unpub/.), 33p. EC, DGXII Environment programme I.1.

Chorowicz, J. et Mukonki, M. B. 1980. Linéaments anciens, zones transformantes récentes et géotectonique des fossés dans l'est Africain, d'après la télédétection et la microtectonique. Rapport Annuel 1979, pp143-146. Département de Géologie et Minéralogie, Musée Royal de l'Afrique Centrale. Tervuren, Belgium.

Clark, J. D., Haynes, C. V., Mawby, J. E. and Gautier, A. 1970. Interim report on paleo-antropological investigations inthe Malawi rift. Quaternaria 13, 305-354.

Cloetingh, S. and Kooi, H. 1992. Intraplate stress and dynamics aspects of rift basins. In: Geodynamics of Rifting, vol. II. Thematic discussions (Edited by Ziegler, P. A.) Tectonophysics 215, 67-85.

Crossley, R. 1982. Late Cenozoic stratigraphy of the Karonga area in the Malawi rift. Palaeoecology Africa $15,139-144$

Damblon, F. D., Gerrienne, Ph., d'Outrelepont, H., Delvaux, D., Beeckman, H. and Back, S. 1998. Identification of a fossil wood speciemen in the Red Sandstone Group of southwestern Tanzania: stratigraphical and tectonic implications. In: Tectonics, sedimentation and volcanism in the East African Rift System (Edited by Delvaux, D. and Khan, M. A.) Journal African Earth Sciences 26, 387-396.

Damnati, B. and Taieb, M. 1995. Solar and ENSO signatures in laminated deposits from lake Magadi (Kenya) during the Pleistocene/Holocene transition. Journal African Earth Sciences 21, 373-382. 
Delvaux, D. 1993a. Quaternary stress evolution in East Africa from data of the western branch of the East African rift. In: Geoscientific Research in Northern Africa (Edited by Thorweihe, U. and Schandelmeier, H.) pp315-318. Balkema, Rotterdam, Brookfield.

Delvaux, D. 1993b. The TENSOR program for paleostress reconstruction: examples from the east African and the Baikal rift zones. EUGVII, 4-8 april 1993, Strasbourg. Terra Nova Abstract Supplement $N^{\circ} 15,216$.

Delvaux, D. and Hanon, M. 1993. Neotectonics of the Mbeya area, SW Tanzania. Rapport Annuel 1991-1992, pp87. 97. Département de Géologie et Minéralogie, Musée Royal de l'Afrique Centrale, Tervuren, Belgium.

Delvaux, D., Levi, K., Kajara, R. and Sarota, J. 1992. Cenozoic paleostress and kinematic evolution of the Rukwa - North Malawi rift valley (East African rift system). Bulletin Centres Recherches Exploration Production Elf-Aquitaine 16, 383-406.

Delvaux, D., Moeys, R., Stapel, G., Petit, C., Levi, K., Miroshnichenko, A., Ruzhitch, V. and Sankov, V. In press. Paleostress reconstructions and geodynamics of the Baikal region, Central Asia. Part 11: Cenozoic tectonic stress and fault kinematics. Tectonophysics.

De Vos, A. 1994. Pliocene en Kwartaire evolutie van het Livingstone bekken (Malawi rift, Tanzanie) afgeleigd uit hoge-resolutie reflectieseismische profielen. M. Sc. dissertation $91 \mathrm{p}$. University of Gent, Belgium.

Dypvik, H., Nestby, H., Rudent, F., Aagaard, P., Johansson, T., Msindai, J. and Massay, C. 1990. Upper Paleozoic and Mesozoic sedimentation in the Rukwa-Tukuyu Region, Tanzania. Journal African Earth Sciences 11, 437-456.

Ebinger, C. J., Deino, A. L., Drake, R. E. and Tesha, A. L. 1989. Chronology of volcanism and rift basin propagation: Rungwe volcanic province, East Africa. Journal Geophysical Research 94, 15,783-15,803.

Ebinger, C. J., Deino A. L., Tesha A. L., Becker, T. and Ring, U. 1993. Regional tectonic controls on Rift Basin Morphology: Evolution of the Northern Malawi (Nyasa) Rift. Journal Geophysical Research 98, 17,821-17,836.

Finney, B. P. and Johnson, T. C. 1991. Sedimentation in lake Malawi (East Africa) during the past 10,000 years: a continuous paleoclimatic record from the southern tropics. Palaeogeography, Palaeoclimatology, Palaeoecology 85 , 351-366.

Haberyan, K. A. 1987. Fossil diatoms and the paleolimnology of Lake Rukwa, Tanzania. Freshwater Biology 17, 429436.

Haberyan, K. A. and Hecky, R. E. 1987. The Late Pleistocene and Holocene stratigraphy and paleolimnology of Lakes Kivu and Tanganyika. Palaeogeography, Palaeoclimatology, Palaeoecology 61, 169-197.

Hamroush, H. A. and Stanley, J. D. 1990. Paleoclimatic oscillations in East Africa interpreted by analysis of trace elements in Nile delta sediments. Episodes 13, 264-288.

Harkin, D. A. 1960 . The Rungwe volcanics at the northern end of Lake Nyasa. Geological Survey Tanganyika, Memoir $11,172 \mathrm{p}$.

Jackson, J. and Blenkinshop, T. 1997. The BililaMtakataka fault in Malawi: An active, 100-long, normal fault segment in thick seismogenic crust. Tectonics $\mathbf{1 6}$, 137-150.

Kazmin, V. 1980. Transform faults in the East African rift system. In: Geodynamic Evolution of the Afro-Arabian Rift System. Academia Nazionale Lincei, Roma. Atti dei convegni Lincei 47, 65-73.

Kilembe, E. A. and Rosendahl, B. R. 1992. Structure and stratigraphy of the Rukwa Basin. Tect nophysics 209, 143-158.
King, L. C. 1963. South African Scenery 308p. Oliver and Boyd, Edinburgh.

Lenoir, J.-L., Liégeois, J.-P., Theunissen, K. and Klerkx, J. 1994. The Palaeoproterozoic Ubendian shear belt in Tanzania: geochronology and structure. Journal African Earth Sciences 19, 169-184.

Mbede, E. I. 1993. Tectonic development of the Rukwa Rift basin in SW Tanzania. Berliner Geowissenschaftliche Abhandlungen A152, 92p.

McConnell, R. B. 1947. Geology of the Namwele-Nkomolo Coal Field. Geological Survey Tanganyika Short Paper 27. $54 \mathrm{p}$.

McConnell, R. B. 1972. Geological development of the rift system of eastern Africa. Geological Society America Bulletin 83, 2549-2572.

Morley, C. K., Cunningham, S. M., Harper, R. M. and Wescott, W. A. 1992. Geology and geophysics of the Rukwa rift, East Africa. Tectonics 11, 68-81.

Owen, R. B., Crossley, R., Johnson, T. C., DavisonHirschmann, S., Tweddle, D. and Engstrom, D. E. 1990. Major low levels of Lake Malawi and implications for evolution rates in cichlid fishes. Royal Society London Proceedings B240, 519-553.

Peirce, J. and Lipkov, L. 1988. Structural interpretation of the Rukwa rift, Tanzania. Geophysics 53, 824-836.

Quennell, A. M., McKinlay, A. C. M. and Aitken, W. G. 1956. Summary of the geology of Tanganyika. Part I: Introduction and stratigraphy. Geological Survey Tanganyika Memoir 1, 264p.

Ring, U., Betzler, C. and Delvaux, D. 1992. Normal vs. strikeslip faulting during rift development in East Africa: the Malawi rift. Geology 20, 1015-1018.

Scholz, C. A. and Rosendahl, B. R. 1988. Low lake stands in Lakes Malawi and Tanganyika, East Africa, delineated from multifold seismic data. Science 240, 1645-1648.

Stewart, I. S. and Hancock, P. L. 1991. Scales of structural heterogeneity within neotectonic normal fault zones in the Aegean region. Journal Structural Geology 13, 191 204.

Strecker, M. R., Blisniuk, P. M. and Eisbacher, G. H. 1990 Rotation of extension direction in the central Kenya Rift. Geology 18, 299-302.

Sylvester, A. G. 1988. Strike-slip faults. Geological Society America Bulletin 100, 1666-1703.

Talbot, M. R. and Livingstone, D. A. 1989. Hydrogen index and carbon isotopes of lacustrine organic matter as lake level indicators. Palaeogeography, Palaeoclimatology, Palaeoecology 70, 121-137.

Theunissen, K., Lenoir, J.-L., Liégeois, J.-P., Delvaux, D. et Mruma, A. 1992. Empreinte mozambiquienne majeure dans la chaîne ubendienne de Tanzanie sud-occidentale: géochronologie U-Pb sur zircon et contexte structural. Compte Rendus Académie Sciences Paris, Série // 314, 1355-1362.

Theunissen, K., Klerkx, J., Melnikov, A. and Mruma, A. 1996. Mechanism of inheritance of rift faulting in the western branch of the East African Rift, Tanzania. Tectonics 15, 776-790.

Tiercelin, J.-J., Chorowicz, J., Bellon, H., Richert, J.-P., Mwambene, J. T. and Walgenwitz, F. 1988. East African rift system: offset, age and tectonic significance of the Tanganyika-Rukwa-Malawi intracontinental fault zone. Tectonophysics 148, 241-252.

Van der Beek, P., Mbede, E., Andriessen, P. and Delvaux, D. 1998. Denudation history of the Malawi and Rukwa Rift flanks (East African Rift System) from apatite fission track thermochronology. In: Tectonics, sedimentation and volcanism in the East African Rift System (Edited by Delvaux, D. and Khan, M. A.) Journal African Earth Sciences 26, 363-385. 
Vittori, E., Delvaux, D. and Kervyn, F. 1997. Kanda Fault: a major seismogenic element west of the Rukwa rift (East Africa, Tanzania). In: Paleoseismology: using Quaternary geology to understand past earthquakes (Edited by Hancock, P. L. and Michetti, A. L.) Journal Geodynamics 24, 139-153.

Wescott, W. A., Krebs, W. K., Engelhardt, D. W. and Cunningham, S. M. 1991. New biostratigraphic age dates from the Lake Rukwa Rift Basin in Western Tanzania. American Association Petroleum Geologists Bulletin 75, 1255-1263.

Williams, T. M., Henney, P. J. and Owen, R. B. 1993. Recent eruptive episodes of the Rungwe volcanic field (Tanzania) recorded in lacustrine sediments of the Northern Malawi rift. Journal African Earth Sciences 17, 33-39.

Wheeler, W. H. and Karson, J. A. 1994. Extension and subsidence adjacent to a "weak" continental transform: an example of the Rukwa Rift, East Africa. Geology 22, 625-628.
Ziegler, P. A. 1996. Geodynamic processes governing development of rifted basins. In: Geodynamic evolution of sedimentary basins (Edited by Roure, F., Ellouz, N., Shein, V. S. and Skvortsov, 1.) pp19-67. Technip, Paris.

\section{Geological and Topographical maps}

Geological map of Itaka, Sheet 243; 1:125 000. 1962 Compiled by Kennerley, J. B. Geological Survey of Tanganyika, Dodoma.

Geological map of Mpui, Sheet 225; 1:125 000. 1962. Compiled by van Loenen, R. E. and Kennerley, J. B. Geological Survey of Tanganyika, Dodoma.

Topographical maps of Tanzania, Sheets 207, 208, 242, 243,$244 ; 1: 50000.1983$. Sheets 169, 188, 225, 226 227,$228 ; 1: 50000.1984$. Sheet 189; 1:50 000. 1985. Compiled by the Surveys and Mapping Division, Ministry of Lands, Housing and Urban Development, Dar-es-Salaam, Tanzania. 